\title{
Tap and Reposition Youth (TRY): Providing social support, savings, and microcredit opportunities for young women in areas with high HIV prevalence
}

Annabel Erulkar

Population Council

Judith Bruce

Population Council

Aleke Dondo

Jennefer Sebstad

James K. Matheka

Population Council

See next page for additional authors

Follow this and additional works at: https://knowledgecommons.popcouncil.org/departments_sbsr-pgy

Part of the Behavioral Economics Commons, Demography, Population, and Ecology Commons, Family, Life Course, and Society Commons, and the International Public Health Commons How does access to this work benefit you? Let us know!

\section{Recommended Citation}

Erulkar, Annabel, Judith Bruce, Aleke Dondo, Jennefer Sebstad, James K. Matheka, Arjmand Banu Khan, and Anne Gathuku. 2006. "Tap and Reposition Youth (TRY): Providing social support, savings, and microcredit opportunities for young women in areas with high HIV prevalence," SEEDS no. 23. New York: Population Council. 


\section{Authors}

Annabel Erulkar, Judith Bruce, Aleke Dondo, Jennefer Sebstad, James K. Matheka, Arjmand Banu Khan, and Anne Gathuku

This case study is available at Knowledge Commons: https://knowledgecommons.popcouncil.org/departments_sbsr- 
Tap and Reposition Youth (TRY)

Providing Social Support, Savings, and Microcredit Opportunities for Young Women in Areas with High HIV Prevalence

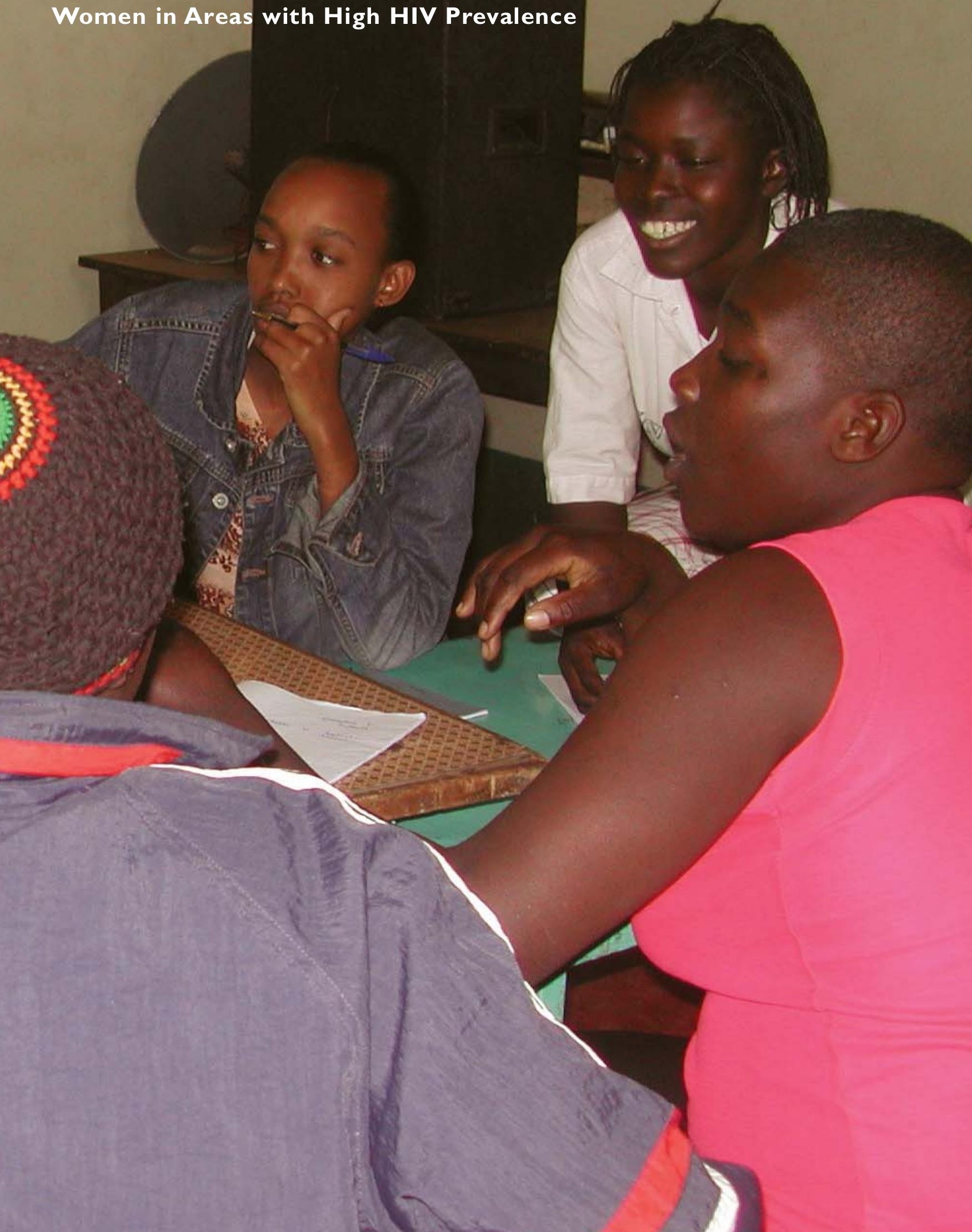




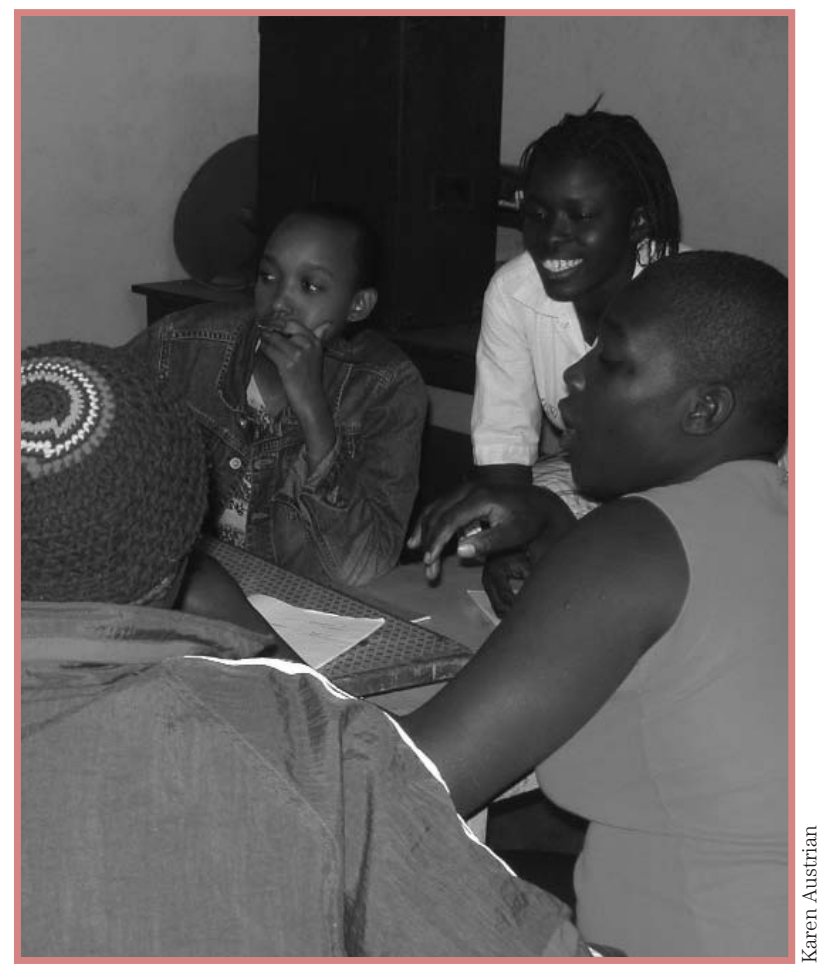

\section{Tap and Reposition Youth (TRY)}

Providing Social Support, Savings, and Microcredit Opportunities for Young Women in Areas with High HIV Prevalence

Annabel Erulkar, Judith Bruce, Aleke Dondo, Jennefer Sebstad, James Matheka, Arjmand Banu Khan, and Ann Gathuku 


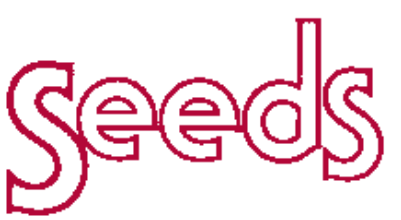

is a pamphlet series developed to meet requests from all over the world for information about innovative and practical program ideas advanced to address the economic roles and needs of low-income women. The pamphlets are designed as a means to share information and to spark new initiatives based on positive experiences from projects that are working to help women generate livelihoods and to improve their economic status. The projects described in this and other issues of SEEDS have been selected because they have served not only to strengthen women's productive roles but also to integrate women into various sectors of social and economic development. All projects documented in the SEEDS series involve women in decisionmaking, organize women locally, and address broader policy issues that affect the economic roles of women.

These reports are not meant to be prescriptive, because every development effort will face different problems and possibilities. Rather, they have been written to describe the history of an idea and its implementation in the hope that the lessons learned can be useful in a variety of settings. They are also being written to bring to the attention of those in decisionmaking positions the vital roles that women play not only in the economies of their individual households but also in the economic life of every nation.

This edition of SEEDS is made possible by support of the Ford Foundation and the Population Council.

\section{(f Population Council}

The Population Council is an international, nonprofit, nongovernmental organization that seeks to improve the well-being and reproductive health of current and future generations around the world and to help achieve a humane, equitable, and sustainable balance between people and resources. The Council conducts biomedical, social science, and public health research and helps build research capacities in developing countries. Established in 1952, the Council is governed by an international board of trustees. Its New York headquarters supports a global network of regional and country offices.

Population Council, One Dag Hammarskjold Plaza, New York, New York 10017 USA

Tel: (212) 339-0500, fax: (212) 755-6052

E-mail: pubinfo@popcouncil.org or seedseditor@gmail.com

http://www.popcouncil.org/publications/seeds/seeds.html

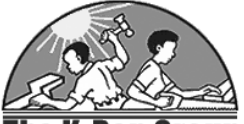

K-Rep Development Agency's mission is to build the field of microfinance through the development of appropriate products and services to create economic opportunities for low-income people and contribute to elimiThe K-Rep Group nating poverty.

K-Rep Development Agency, Mandera Road, Kileleshwa, Post Office Box 10528-00100 Nairobi KENYA

Tel: 4343493/95,0733630062/0722206039

E-mail: kda@k-rep.co.ke

Any part of this publication may be copied or adapted to meet local needs without permission from the Population Council, provided that the parts copied are distributed free or at cost (not for profit) and that the source is identified. The Population Council would appreciate receiving a copy of any materials in which the text is used.

Number 23, $2006 \quad$ ISSN: 073-6833

Copyright () 2006 The Population Council, Inc. 


\section{Table of Contents}

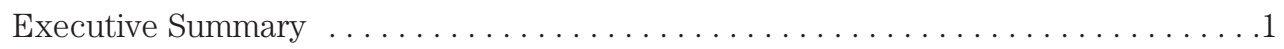

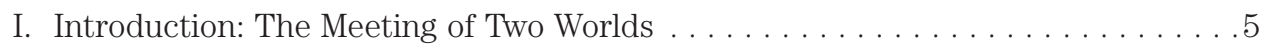

II. The Context: Nairobi's Low-income and Slum Areas . . . . . . . . . . . . . . . 6

III. Poor Adolescents' Education, Livelihoods, and Vulnerabilities . . . . . . . . . . .7

IV. The Coverage and Content of Conventional Programs for Adolescents

in sub-Saharan Africa . . . . . . . . . . . . . . . . . . . . .

V. Finding a Partner for an Adolescent Girls' Livelihoods Program . . . . . . . . . . 10

VI. Microfinance in Historical Perspective . . . . . . . . . . . . . . . . . 11

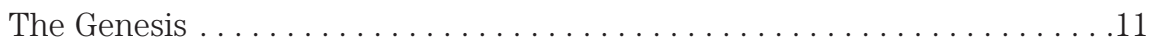

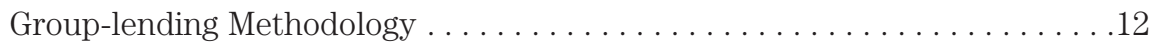

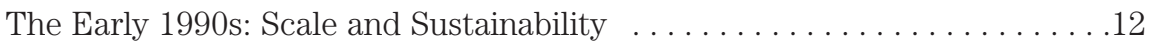

The Late 1990s: Diversification of Financial Products

and Services for the Poor . . . . . . . . . . . . . . . . . . . . . . 13

The Early 2000s: Renewed Interest in Linking Microfinance

to Broader Development Objectives . . . . . . . . . . . . . . . . . . . 14

VII. Group Lending Comes to Kenya . . . . . . . . . . . . . . . . . . . . . . 14

VIII. The Emergence of TAP and Reposition Youth (TRY): Adapting the Adult

Juhudi Model for Adolescent Girls . . . . . . . . . . . . . . . . . . . . . . 15

Creating Awareness and Group Formation . . . . . . . . . . . . . . . . 18

Starting to Save . . . . . . . . . . . . . . . . . . . . . . . . . . . . . . . . . 19

Merry-go-rounds . . . . . . . . . . . . . . . . . . . . . . . 20

How Group Meetings Took on a Life of Their Own $\ldots \ldots \ldots \ldots \ldots \ldots . .21$

Starting to Take Out Loans . . . . . . . . . . . . . . . . . . . . . . . . . 23

IX. Limits of the Initial Microcredit Model in the Context of Girls'

Multidimensional Vulnerability . . . . . . . . . . . . . . . . . . . . 23

Who Are the TRY Girls? Linking Vulnerability to HIV Risks . . . . . . . . . . 26

Expanding Social Support within a Microfinance Program . . . . . . . . . . .28

Adding a New Cadre of Mentors . . . . . . . . . . . . . . . . . . . . 29

Personal Savings . . . . . . . . . . . . . . . . . . . . . . . . . . .

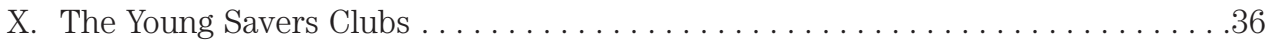

A New Savings Option for Members $\ldots \ldots \ldots . \ldots \ldots \ldots$

XI. More Than Just Repayment Rates: The Impact of Savings and Group-lending

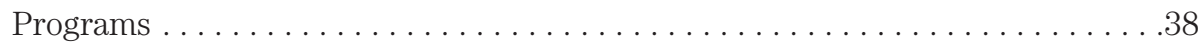

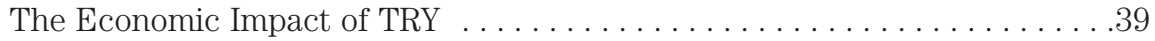

The Impact of TRY on Reproductive Health Knowledge

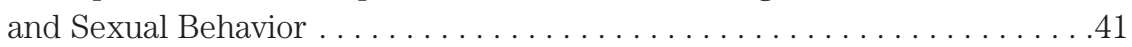

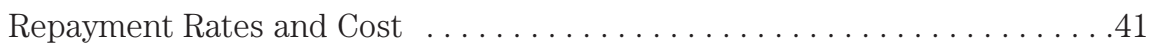

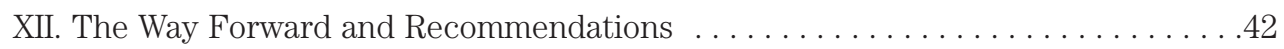

The Heterogeneity of Adolescent Urban Girls . . . . . . . . . . . . . . . . . . . . . . . . . . . . . 43

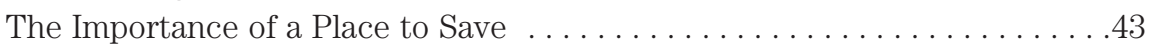

Social Support and Mentoring . . . . . . . . . . . . . . . . . 43

Microfinance Institutions and Their Ability to Stretch . . . . . . . . . . .43

Programming for Differing Conditions and Evolving Capacities . . . . . . . . 44

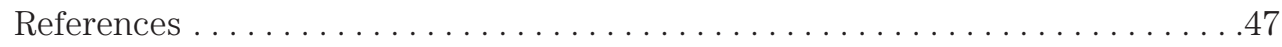




\section{Acknowledgments}

The authors wish to thank the Ford Foundation, DFID (the UK Department for International Development), the Kaufman Family Foundation, the Turner Foundation, and Effie Westervelt for supporting this project. Special thanks are due to Kate McKee, Evelyn Stark, Francis Ayuka, Monique Cohen, and Erica Chong for substantive comments and editorial guidance. 


\section{Executive Summary}

Tap and Reposition Youth (TRY) was a multiphase initiative undertaken by the Population Council and K-Rep Development Agency (KDA), the oldest and largest microfinance institution in Kenya. The overall aim of the project was to reduce adolescents' vulnerabilities to adverse social and reproductive health outcomes, including HIV infection, by improving their livelihoods options. The project was launched in low-income and slum areas of Nairobi, Kenya, where rates of HIV infection are alarming and where young women are disproportionately affected.

TRY targeted out-of-school adolescent girls and young women aged 16-22. ${ }^{1}$ Initially, the microfinance model was an adaptation of the adult juhudi groupbased savings and lending model. The TRY model evolved over the course of the experiment, moving from a minimalist savings and credit model to one that expanded upon social support and eventually responded to the particular needs of its vulnerable clientele.

\section{Phase One}

\section{The Minimalist Model: Focusing on Group Formation and Credit}

The pilot phase of TRY began in 1998 and lasted until 2001. Based on the adult juhudi model, roughly 25 girls came together to form a self-help group that was registered by the Ministry of Culture and Social Services (later renamed the Ministry of Gender, Sports, Culture and Social Services). Within the larger group of 25, subgroups were formed of five members each, termed watano, the Kiswahili word for five.

Groups received a six-day training that included business management and planning skills, entrepreneurial skills, life skills, and gender roles. The pilot was designed so that starting in the initial group meetings, girls contribute weekly savings to a group account that will eventually constitute collateral for microloans. Although members' contribution to the group's savings continues throughout their participation, access to savings is restricted; funds can be withdrawn only when a girl leaves the program. In order to obtain a loan, a participant devises a business plan and makes related applications that are reviewed and agreed upon by the group members. Girls received loans in turns; two watano members receive initial loans, and the remaining members receive loans once their comembers have demonstrated their reliability through regular weekly repayments.

In this first phase, loan amounts ranged from US\$40 to $\$ 200$. Repayment began the week following loan disbursement at a 15 percent interest rate. The businesses undertaken were of the girls' choosing and included hairdressing salons, food stands, petty trade, and construction of simple housing for rent.

Girls' participation in this first phase was very active, and repayment rates were high. Eventually, however, repayment rates dropped, the groups dissolved, and girls started to drop out of the program. The initial model placed heavy emphasis on the provision of cred-

\footnotetext{
${ }^{1}$ In the first phase of TRY, the target age group was 16-24.
} 
it as the driving force of TRY, with little recognition of the girls' vulnerabilities, their need for social support, and the importance of their having safe and accessible savings as a cushion against emergencies. The first phase of TRY was evaluated, and collaborators devised modifications to the model for the program's second phase.

\section{Phase Two}

\section{Strengthening the Social Intermediation Components within TRY}

The default and drop-out rates that ended TRY's first phase forced K-Rep and the Population Council to reexamine the conditions of girls' lives and the diverse circumstances of TRY participants. Only 12 percent of TRY participants lived with both parents. The remainder lived in a variety of situations: in single-parent households, with a boyfriend, or heading their own households. More than half of the participants had migrated to Nairobi, mainly in search of jobs; only about half reported having many friends or people to whom they could turn for support. Only 37 percent of the girls reported that their first experience of sex was wanted, and 24 percent reported that they had traded sex for money, gifts, or support.

The first phase of TRY focused on the provision of credit, but for many TRY girls, the solidarity of the groups represented a surrogate home and a source of much-needed social support and camaraderie. The program's collaborators decided to expand upon the social support they offered by adding a number of adult mentors to work in parallel with the credit officers. While the K-Rep credit officers focused on financial functions, the mentors provided social support and counseling, organized events, seminars, and day trips, and provided referrals when they were needed. Nine mentors were recruited from diverse backgrounds, such as social work, community development, the health sector, and successful small businesses.

As a group, the mentors and credit officers organized larger educational seminars to which all TRY participants could come together for information and discussions with guest speakers. Large group seminars were organized concerning HIV/AIDS, domestic violence and gender-based violence, women's rights, drug and alcohol abuse, male-female relationships, and family planning. In the context of HIV/AIDS, considerable information on a variety of topics was provided, including voluntary counseling and testing, nutrition in HIV management, mother-tochild transmission, and antiretroviral therapy. Initially, the girls responded enthusiastically to the mentors, taking their presence as a sign that K-Rep cared about them and was not interested only in providing financial services.

Nevertheless, girls continued to drop out of TRY, largely because they were concerned for the security of their savings, especially when comembers defaulted on loans, or because they needed to access their accumulated savings quickly in times of emergency, savings that were locked up as group collateral. Moreover, although most girls valued the group meetings and friendships they gained, they were not interested in the continuous lending that the program emphasized. Project managers, therefore, devised a way to offer girls safe and accessible savings together with safe and supportive peer-group experiences.

\section{Phase Three Forming Young Savers Clubs and Providing Safe Spaces}

In early 2004, the Young Savers Clubs were established as independent from the TRY juhudi groups. Young Savers 
were recruited through existing TRY members, the credit officers, mentors, and other community members such as social workers. As with TRY, members of the Young Savers Clubs form themselves into groups consisting of 20 to 25 members and conduct weekly meetings that are led by a credit officer or a mentor. By the end of 2004, 123 young women had become members and were contributing savings, even if not on a regular basis.

The club meeting is organized like the TRY groups with an initial roll call of members by the group chairwoman. The girls deposit their savings with the treasurer, using the passbook system. The clubs meet on a weekly basis and hold group discussions, engage with mentors, and participate in recreational activities such as sports and games. The savings are held in one large account maintained by K-Rep for all of the savings groups. Should an individual wish to withdraw money, she fills out a withdrawal form, and the money is given to her the following week. Girls appreciate being able to store their money in a safe place, and many mentioned that the group helps them to become disciplined in money matters. As with the TRY groups, the girls also appreciate the friendships they form:

I have tried [saving money at] home many times, but I see something like shoes, and I break the tin and use it [the money]. With Young Savers, the money is safe because it is in the bank. It cannot be given to someone else, like my husband when he sees something he wants to buy with my money.

—Age 19, married, no children, nine years of education

What attracted me, apart from saving, are the seminars. I especially like the way we are taught about how to run businesses and about nutrition and how to keep fit. We do exercises for about 20 minutes. It also takes away my idle- ness. In the group, problems-even individual problems-are less troublesome when we share them.

-Age 20, married, one child, eight years of education

Young Savers Clubs offer girls an integrated livelihood and social support experience without the pressure associated with loans and repayment. When the voluntary savings option was also offered to TRY clients, nearly all joined Young Savers in addition to their regular TRY membership, demonstrating the importance of and demand for safe, accessible savings for girls and young women.

\section{Phase Four \\ Programming for Differing Conditions and Evolving Capacities}

The experience of TRY underscored the vulnerability of girls and young women and highlighted their diversity despite their common residence in a poor urban community. It also underscored girls' differing capabilities and capacities during their transition to adulthood. The initially rigorous microfinance model piloted for TRY was appropriate for only a small subset of the most capable and least vulnerable girls and young women. For the majority of young women, entrepreneurship and repeated borrowing were not primary concerns. Rather, their fundamental needs related to acquiring social capital, including social support groups, friendships, mentorships, physical safety, and the opportunity to save their money in a safe, accessible place. When these needs are met, entrepreneurship and use of credit opportunities may follow.

A reliable and safe group structure should form the core of programs for vulnerable girls, with participation constructed as a positive experience. The most vulnerable girls need a place apart from 
their families for dialogue, support, crisis intervention, the protection of savings, and the development of rudimentary livelihood skills. Only when such fundamental elements of social capital are in place will girls be able to take advantage of economic options.

Program collaborators suggest a livelihoods program model that takes account of the capabilities and evolving capacities of girls and young women. Programs for younger, more reticent, more vulnerable girls may begin with rudimentary safe venues, basic education, and skills training, and perhaps savings and financial education. Programs for older, more experienced, and less vulnerable girls may include vocational, technical, or businessskills training, and microcredit and other financial services (see Table A).

Table A Staged program model for adolescents, by type of program, according to type of beneficiaries and providers

\begin{tabular}{|c|c|c|c|}
\hline Type of program & $\begin{array}{l}\text { Program activities for younger, } \\
\text { more reticent adolescents living } \\
\text { in constrained circumstances }\end{array}$ & $\begin{array}{l}\text { Program activities for older, } \\
\text { bolder adolescents living in } \\
\text { better circumstances }\end{array}$ & Providers \\
\hline Social intermediation & $\begin{array}{l}\text { Group meetings in safe and } \\
\text { appropriate venues } \\
\text { Age-appropriate learning activities } \\
\text { Literacy and numeracy training } \\
\text { Life-skills training } \\
\text { Health education } \\
\text { Financial education } \\
\text { Leadership/group participation } \\
\text { Simple technologies } \\
\text { Livelihood-skills training } \\
\text { Rights education } \\
\text { Social support provided by mentors } \\
\text { Organized sports and recreation }\end{array}$ & $\begin{array}{l}\text { Vocational training } \\
\text { Technical training } \\
\text { Business-skills training }\end{array}$ & $\begin{array}{l}\text { Youth-serving } \\
\text { organizations } \\
\text { Vocational, technical, } \\
\text { or business training } \\
\text { institutions } \\
\text { Sports organizations } \\
\text { Informal education } \\
\text { programs } \\
\text { Other organizations } \\
\text { providing nonfinancial } \\
\text { services }\end{array}$ \\
\hline Financial services & $\begin{array}{l}\text { Promotion of savings linked to } \\
\text { financial education }\end{array}$ & $\begin{array}{l}\text { Credit } \\
\text { Other financial services } \\
\text { (insurance, money transfer) }\end{array}$ & $\begin{array}{l}\text { Microfinance } \\
\text { institutions } \\
\text { Credit unions } \\
\text { Banks }\end{array}$ \\
\hline Other & $\begin{array}{l}\text { Exposure to world beyond home } \\
\text { through visits and exchanges }\end{array}$ & $\begin{array}{l}\text { Work experience through } \\
\text { facilitation of apprentice- } \\
\text { ships, business mentoring, } \\
\text { and other on-the-job } \\
\text { training }\end{array}$ & $\begin{array}{l}\text { Youth-serving } \\
\text { organizations } \\
\text { Business-development } \\
\text { organizations } \\
\text { Business associations }\end{array}$ \\
\hline
\end{tabular}




\title{
Tap and Reposition Youth (TRY)
}

\author{
Providing Social Support, Savings, and \\ Microcredit Opportunities for Young \\ Women in Areas with High HIV Prevalence
}

\author{
by Annabel Erulkar, Judith Bruce, Aleke Dondo, Jennefer Sebstad, \\ James Matheka, Arjmand Banu Khan, and Ann Gathuku
}

\section{Introduction: \\ The Meeting of Two Worlds}

This case study brings together two story lines: The first is the story of an evolving microfinance approach to poverty alleviation in a sub-Saharan African city. The second is the story of vulnerable adolescent girls in that same city-especially those living in slum areas where the HIV pandemic is not only selective of young people, but especially of girls. In subSaharan Africa, three-fourths of all new HIV infections in the 15-24-year age group attack females (Lewis 2004).

The story lines meet in a collaborative effort of the Population Council and KRep Development Agency (KDA, formerly the Kenya Rural Enterprise Program) to bring support and financial services to girls in the poorest neighborhoods of Nairobi. When the project began in the late 1990s, the HIV epidemic in Kenya was alarming but the pattern of infection, including the extent to which young women were affected, was not yet apparent. K-Rep had two decades of experience in developing financial products to reach low-income populations in Kenya, mainly using a microfinance model developed in Asia. This model first took root in rural Bangladesh, where the majority of beneficiaries were married women in their mid-twenties to early forties. Most of these women had completed much of their childbearing and were highly motivated to improve their economic status. In contrast, girls in Africa's informal urban settlements are younger (aged 15-24), most have not begun childbearing, and they are largely inexperienced in managing their economic lives. Many of the girls live apart from their parents, many do not attend school, and some have migrated to the city from rural areas. Little in their lives is settled. Most have no established families, belong to no formal groups, and have a limited network of friends. Few have bank accounts, access to loans, or marketable skills. Their contact with health and social service structures is minimal.

A large number of girls across subSaharan Africa share these vulnerabilities. Among 12 countries with significant HIV epidemics, an average of 33 percent of urban girls aged 10-14 are living with neither parent, and 28 percent are living with only one parent (Bruce 2005). Compared with girls who live with both parents, such girls are much less likely to attend school. A high proportion of girls in many cities have migrated from rural areas in search of better prospects but with little social capital, limited social networks or trusted relationships, and few safe economic opportunities. Many of these girls are doubly disadvantaged in that they live apart from the protective structures of family and away from communities where they are known and have 
networks. Many girls fall into abusive relationships, exchange sex for money or support, or form serial relationships that offer only rudimentary security. Conventional youth-development programs, including youth centers, peer education, and school-based family-life education, typically target the 10-24 age group. Girls in these circumstances are largely untouched by such programs, however.

These multidimensional vulnerabilities were weighed as K-Rep and the Population Council began to design a strategy to offer social support, economic opportunities, and savings and credit opportunities to meet the needs of adolescent girls in the context of urban poverty and the HIV epidemic in Kenya.

\section{The Context: Nairobi's Low-income and Slum Areas}

Until recently, little understanding has existed concerning the lives of adolescent girls in low-income and slum areas of Nairobi or, indeed, in other urban centers of Africa. Africa's largest cities attract migrants from rural areas, especially those in search of education and livelihood opportunities. Increasingly, economically active adolescents and young men and women are dominating urban areas in Africa (APHRC 2002).

Kenya has one of the highest rates of urbanization in the world; in 1990, 24 percent of Kenyans lived in urban areas, but by 2000 that figure had risen to 33 percent. Nairobi alone had grown by more than 7 percent per year (Garenne 2003; United Nations University 2004). Nairobi, with a population of more than two million, is anticipated to increase by five million residents in the next 15 years. Most of these people will live in low-income and "informal settlements," or slum areas (Zulu et al. 2000). The term "informal settlements" underscores their imperma- nence and implicitly justifies their lack of government infrastructure and services, including water, electricity, health services, and law enforcement. Living conditions here are deplorable; toilets are in short supply and garbage collection virtually nonexistent. Many residents live in one-room houses made of semipermanent materials such as mud, wooden planks, or metal sheets. There is no drainage system, so that during the rainy season, water seeps into one-room dwellings, and people have no alternative but to stay in houses that are flooded ankle-deep with rainwater. More than 50 percent of the population lives below the poverty line (APHRC 2002). Residents eke out their sustenance in whatever way they can, mostly by informal-sector work such as petty trade or casual labor. Not surprisingly, these areas are ridden with crime.

Armed with only a little education and the interest and will to work, many young Kenyan women in such urban environments experience their transition to adulthood.

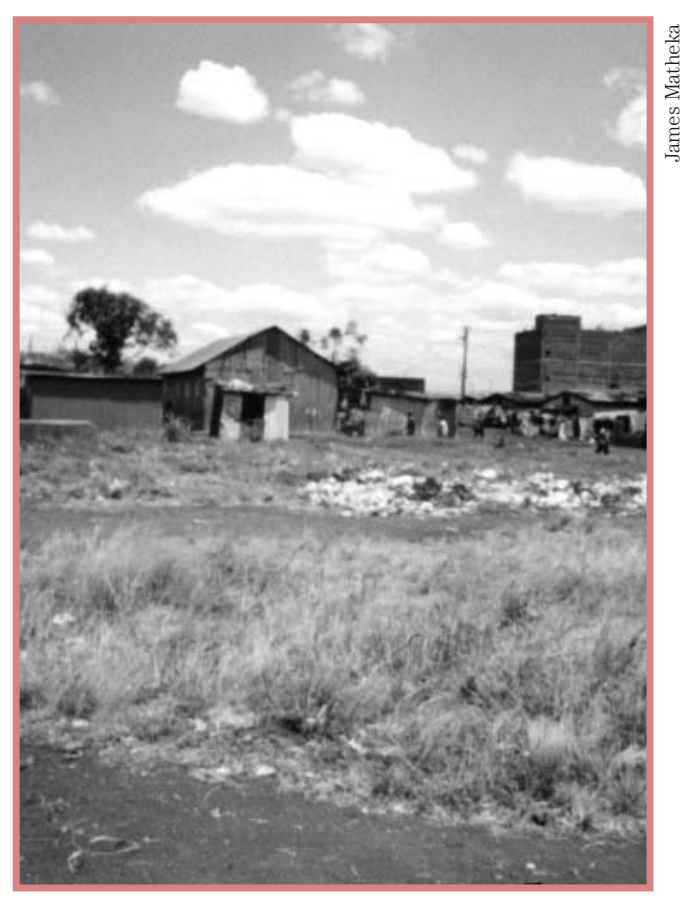




\section{Poor Adolescents' Education, Livelihoods, and Vulnerabilities}

Compared with young people in other African countries, Kenyan adolescents enjoy high rates of educational participation and attainment. Nationally, 90 percent of younger adolescents (aged 1213) are enrolled in school (Mensch et al. 1998), and approximately one-third of young people (31 percent of boys and 28 percent of girls) in Kenya reach secondary school (APHRC 2002; UNICEF 2004). Rates of educational attainment are generally higher in Nairobi; 73 percent of boys and 50 percent of girls reach secondary school. Among adolescents living in Nairobi's slums, however, only 40 percent of boys and 33 percent of girls have some secondary education.

Although gender disparities in education are not evident for younger Kenyans, by late adolescence, many more boys than girls remain in school. Among young people aged 15-17, 60 percent of boys and 78 percent of girls in the slum areas of Nairobi are not attending school. Poverty resulting in the inability to pay school fees is cited as the main reason for nonattendance (APHRC 2002). Large proportions of young people attend school at the wrong grade for their age, which limits educational quality as well as the schools' effectiveness as an instrument of socialization (Lloyd 2005). Whether skilled or unskilled, educated or not, these young people, especially young women, have few employment opportunities.

Nearly one in five Nairobi residents in the labor force are estimated to be unemployed (Government of Kenya 1999). Unemployment rates are far high- er for females than for males. The highest rates of unemployment are concentrated among young women. Nationally, 24 percent of young women aged 15-19 are unemployed, compared with 15 percent of boys of the same age. Unemployment rates for Nairobi girls are likely to be much higher; one survey revealed that 66 percent $^{2}$ of girls aged 15-19 in the Nairobi slums are not working and cited unemployment as the most pressing personal concern of the survey respondents (APHRC 2002).

Adolescents are often assumed to be living with and receiving support from their parents. In fact, many adolescent Kenyan girls, especially those in urban slum areas, are not. In Nairobi slums, 58 percent of girls aged 15-17 are not living with either parent, compared with 41 percent of boys of the same age. Many girls are living with extended family members or with nonrelatives, often as domestic servants. ${ }^{3}$

The vast majority of girls not living with their parents are also not attending school (83 percent). Without parental or school support, and living without means to support themselves, these girls are among Kenya's most vulnerable citizens and among those most at risk of HIV infection.

Rates of HIV in Kenya are among the highest in the world; an estimated 8.7 percent of women aged 15-49 and 4.5 percent of men aged 15-54 are infected with the virus. Rates of infection in urban areas are much higher than those in rural areas, and young women are disproportionately affected. Table 1 shows HIV prevalence among adolescents and young people living in Nairobi, as measured for the 2003 Kenya Demographic and Health Survey (Central Bureau of Statistics et al. 2004).

\footnotetext{
2 This calculation is based on the proportion of all women interviewed in this age group and does not take into account those who are in the labor force compared with those who are not in the labor force.

${ }^{3}$ A recent study in slum areas of Addis Ababa, Ethiopia, found that 15 percent of girls aged 10-19 were employed as domestic workers, often for as little as $\$ 1.50$ a month (Erulkar et al. 2004). Information about these girls may not be captured by household surveys because they are often overlooked members of the household.
} 
Table 1 Prevalence (percent) of HIV infection among young people, by sex, Nairobi, Kenya, 2003

\begin{tabular}{lrr}
\hline Age group & $\begin{array}{r}\text { Males } \\
(\mathrm{n}=\mathbf{3 6 8})\end{array}$ & $\begin{array}{r}\text { Females } \\
(\mathrm{n}=434)\end{array}$ \\
\hline $15-19$ & 0.0 & 5.1 \\
$20-24$ & 2.6 & 5.4 \\
$25-29$ & 3.2 & 18.3
\end{tabular}

Source: Population Council tabulations from the 2003 Kenya Demographic and Health Survey (Central Bureau of Statistics et al. 2004).

The higher rates of HIV infection among girls are partly due to biological susceptibility. Moreover, sexual activity-whether voluntary or not-seems to start earlier for adolescent girls living in the slums compared with those living in other parts of Kenya, with the median age of initiation estimated at 15 years in slum areas of Nairobi and at 18 years outside slum areas (Zulu et al. 2000). Twenty-one percent of sexually active Nairobi girls aged 15-19 reported having exchanged sex for money or gifts, underscoring the extent to which the most vulnerable girls rely on sex as a source of support in desperate circumstances.

It happens. . . yes ... that you might be having a source of getting money, but at that time, you do not have a way of getting money. So you just have to go [and have sex]. Even if they tell you that they will give you 50 shillings, you will godepending on the problem you have.

-Participant in focus-group discussion among females aged 18-24, Embakasi, Nairobi, cited in Zulu et al. 2000.

Cases of people having many sexual partners, especially women, are common here. These cases are common because of poverty There are those women who depend on men for their survival, and so they have to spread their chances by having many men who can support them, so that if one fails, the other one will take over.

-Participant in focus-group discussion with males aged 25-49, Kibera slum,

Nairobi, cited in Zulu et al. 2000.
Recent research in South Africa suggests that girls' lack of social connectedness is linked to their increased risk of experiencing coerced sex. Girls' socioeconomic status was strongly related to the likelihood that they had exchanged sex for gifts or money; girls reported more episodes of exchanging sex for gifts or money at around the time that school fees were due (Hallman 2004; Hallman and Diers 2004). In effect, in an environment where few livelihood opportunities exist and where friends, family, and other social supports are limited, girls often have little choice but to provide sex in exchange for temporary safety, lodging, food, and money.

\section{The Coverage and Content of Conventional Programs for Adolescents in Sub-Saharan Africa}

In the past 20 years, investment in programs for adolescents in Africa has increased, especially through the health sector. Many of these programs focus on reproductive health and the HIV pandemic. Initially, these programs were mounted in response to observed high rates of premarital pregnancy, schoolgirl dropout, and what was perceived as adolescent risk-taking. More recently, programs have responded to high rates of HIV infection among young people. Although current program efforts are more frequently focused on HIV and are increasingly participatory, they remain based on a limited number of models, including youth centers, peer education, school-based family-life/sex education, and youth-targeted media programs. Most focus on increasing young people's knowledge of reproductive health and incorporate cautionary messages about the dangers associated with unprotected sex. 


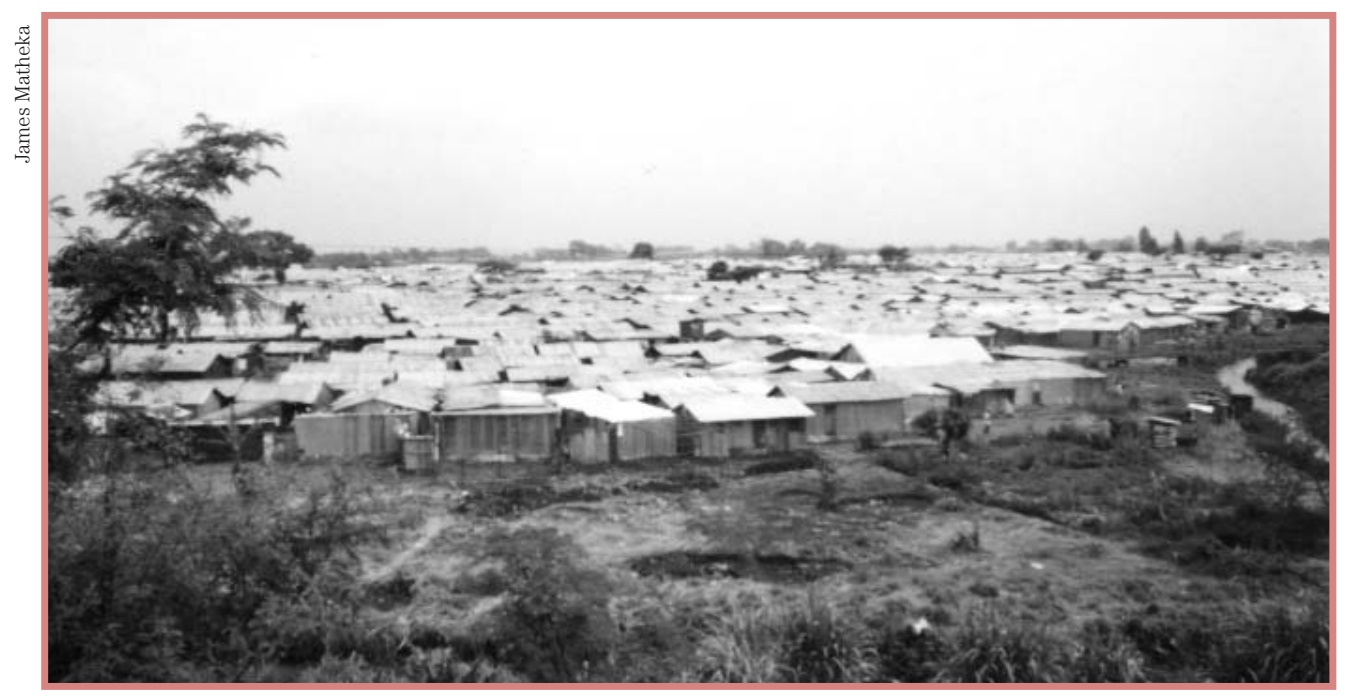

Target audiences for most youth programs are broad, typically covering a 15year age range and including both boys and girls. As a result of casting such a wide net, many programs become ineffective. Generally, little programmatic specificity exists with regard to the circumstances of girls compared with boys, the various life stages and age groups of young people, or the special circumstance of vulnerable subgroups, such as young people living without parents, migrants, or married adolescents. Perhaps for this reason, programs that are meant for both boys and girls mainly are reaching boys and not girls. Evaluations of youth centers in four African locations, including Nairobi, found that boys, especially older boys, dominate activities at these centers (Erulkar and Mensch 1997; Phiri and Erulkar 1997; Glover et al. 1998; Erulkar et al. 2001). Many young women found such centers to be hostile, intimidating, and dangerous environments. In some cases, girls were harassed when they visited the centers. Furthermore, many girls did not want to be associated with the centers that were run by family planning organizations because they bear an undesirable association with sexual activity.

Similarly, peer education generally reaches older boys and the comparative- ly advantaged, especially those who have already benefited from some education. Examination of peer education in Ethiopia found that peer educators more often direct HIV messages toward boys, whereas girls are told about pregnancy and family planning methods (Mekbib et al. 2005). The inclination of peer educators to be silent with adolescent girls about HIV or reticent about suggesting potential strategies for dealing with sexual situations is a serious shortcoming, given that in sub-Saharan Africa, the HIV infection rates of adolescent girls are more than three times those of adolescent boys (UNAIDS et al. 2004). In Ethiopia, nearly 70 percent of the peer-educator interactions included information about HIV, but only 20 percent included information about condoms, suggesting that peer educators speak only about modes of transmission and the need to abstain.

Messages conveyed by many youth programs are not tailored for young people of different ages or for both sexes. They overlook the differences in male and female power in sexual relations as well as the role of poverty in sexual exchanges. Abstinence and safe-sex messages are often based on the assumption that sex is consensual and under the control of the adolescent girl and that 
what is needed is sufficient information and appropriate values (Erulkar 2004). Where programs promote youth-friendly reproductive health services, they may assume, incorrectly, that girls possess adequate mobility and resources to access these services.

Paradoxically, girls' knowledge of and access to health programs and services may be undermined by stigma associated with reproductive health and family planning services. In Kenya, as elsewhere in the developing world, the health sector has taken a leading role in promoting programs to reach young people. Young peoples' interests may, in fact, lie with activities that further their schooling, increase their employment, or offer means of having fun. Population Council research conducted in the mid-1990s explored boys' and girls' perceptions of the programs in their areas. One study compared the reach and acceptability of the Mathare Youth Sports Association (MYSA), a slumbased sports program, to a youth center run by a family planning organization in the same vicinity (Erulkar and Mensch 1997). The sports organizations had far greater coverage and appeal than did the little-known and hardly used youth center, a pattern even more apparent for girls than for boys. Whereas 28 percent of girls living in the catchment areas of the programs knew about MYSA, only 6 percent were aware of the youth center.

\section{Finding a Partner for an Adolescent Girls' Livelihoods Program}

With the notion that poor adolescents and their communities value and need livelihood opportunities, the Population Council's Nairobi office conducted an inventory of programs for adolescents in Kenya. Unsurprisingly, the resulting directory of youth-serving organizations (Khan et al.
1997) was dominated by programs delivered through the health sector. Most focused on messages related to reproductive health and reached young Kenyans through youth centers, peer education, or school-based models. Some of these programs had experimented with income-generating programs for young people or revolving credit schemes, but had failed, largely because the implementing health and development agencies had no experience in designing or running livelihoods programs.

Discussions were held with seven organizations, including three well-established microfinance institutions and organizations that had experimented with economic programs for young people. Many of the institutions had extended credit to women involved in small-scale businesses. None of the microfinance institutions had intentionally targeted women aged 15-24, however; current programs hardly reached this age group. Furthermore, many institutions were unwilling to extend services to this group, reasoning that young people posed a risk to sustainability, that they had insufficient business experience, and that they migrated often or moved when they got married. Moreover, many of the young were refused services because they did not have national identity cards, making any agreements they entered into nonbinding.

The K-Rep group, however, had a long tradition of experimentation and innovation in the microfinance field. Established in 1984, the mission of K-Rep is "to empower low-income [people] and serve as a catalyst for them to increase their participation in the development process and to enhance their quality of life." KRep began as a technical assistance and financing agency for nongovernmental organizations (NGOs) promoting the development of small businesses and microenterprises in Kenya.

Since then, the agency has evolved to include three subsidiaries, K-Rep Ad- 
visory Services, K-Rep Bank, and K-Rep Development Agency (KDA). K-Rep Advisory Services operates in more than 15 African countries, providing technical assistance in building sustainable financial institutions for poor people. With more than 21 branches, K-Rep Bank is the first commercial bank in Kenya specifically designed to help low-income people. The bank offers poor Kenyans a variety of ways to save money safely or to take out loans. The bank also provides an institutional framework through which clients can be offered a range of financial services through the banking sector. The K-Rep Development Agency (KDA) is the development arm of the K-Rep group where new financial services for the poor are developed and tested. Under this division, KDA is currently piloting nine projects in 32 districts of Kenya; more than 62,400 members are using various pilot products. With KDA already dedicated to innovation, experimentation, and institutionalization of successful products, the organization was well positioned to explore new target groups such as young women.

In 1998, the Population Council-a research and development organization concerned with population and reproductive health—and the K-Rep Development Agency formed a synergistic partnership to offer adolescent girls in the slums of Nairobi new social and economic opportunities. The collaboration has evolved into a long-term, three-phase effort (see Table 2 on page 16). A pilot phase ran from 1998 to 2000, including an evaluation conducted at the end of this period (see Sebstad 2001). The first phase consisted of a minimalist group-lending model for assessing the extent to which its provisions were appropriate for young clients. In the second phase, which began in 2001, the original TRY pilot was further modified with the introduction of an integrated socialdevelopment component to complement the group lending and expanded into the Embakasi and Pumwani sections of Nai- robi. During this period, a rural offshoot was established in Kiambu outside Nairobi (see box on page 24: Expanding TRY to Rural Areas). In the third phase, a voluntary savings scheme was added to the original TRY experiment in 2004 as an alternate savings option. These standalone savings clubs were established to attract younger, more vulnerable and, perhaps, risk-averse girls who were not ready for full integration into a groupbased microcredit program. This issue of SEEDS describes the learning process that took place during the three phases.

\section{Microfinance in Historical Perspective}

Before turning to a description of $\mathrm{K}$ Rep's efforts to adapt its "classic" grouplending model to services for adolescent girls, we consider the broader context of the microfinance field.

\section{The Genesis}

Microfinance refers to the provision of financial services including credit, savings, insurance, and money transfer to lowincome households. Microfinance programs first emerged in the 1970s in Bangladesh and Brazil and involved extending very small loans to poor people within groups formed for the purpose. In Bangladesh, the Grameen Bank, one of the early microcredit programs, evolved its approach in rural areas among the landless and semilandless poor, mostly married women who had completed or nearly completed their childbearing. Their residential and social stability allowed them to continue with the same groups over many years and supported the slow process of building assets, including productive assets. In Latin America, microfinance programs emerged during a period of rapid urbanization and involved men and women from poor urban communities. As 
in Bangladesh, most of the women who participated in the program were married and had children.

\section{Group-lending Methodology}

Microfinance programs make loans accessible to poor people by means of group guarantees. Members of credit groups guarantee each other's payments as an alternative to traditional forms of loan collateral such as land, other assets, or income from formal employment. Group-lending models were seen as a promising approach to reducing the cost of lending and increasing repayment rates while reaching the poor with bank services. Credit groups also were seen to have social value in bringing people together to discuss their problems, exchange ideas, and interact within a wider social network. This aspect of the groups was especially important for socially isolated rural women.

The group-lending model was relatively easy to replicate, and microfinance programs for the poor spread throughout Bangladesh and Latin America. By the late 1980s and early 1990s, microfinance programs had sprung up in countries throughout the world. The Kenya Rural Enterprise Program (K-Rep) was one of the first organizations in Africa to adapt the Grameen Bank model.

\section{The Early 1990s: Scale and Sustainability}

In the early 1990s, the microfinance field was characterized by two basic tenets: scale and sustainability. Large-scale outreach was seen as critical to program success and a necessary condition to effect an impact on poverty. The group-lending model was the perfect solution to achieving scale because it cost little and was easily replicated.

Sustainability was necessary for programs to continue to operate over time without subsidies. For microfinance programs, high repayment rates, low program costs, and steady portfolio growth are all key elements of sustainability. To lower program costs, many microfinance programs subscribed to a minimalist approach that focused exclusively on providing financial services without requiring that clients have business training, technical assistance, or other forms of support. This approach also embodied a "borrower knows best" strategy, whereby borrowers are given relatively free rein over use of the money they borrow. This approach marked a major shift in credit programs for the poor; many earlier efforts had targeted credit to particular sectors, enterprises, or assets and included training and other nonfinancial forms of assistance.

At the same time, another undercurrent was felt in the microfinance field: the financial systems approach, which requires microfinance institutions (MFIs) to play an intermediary role, both raising capital through savings and investments and lending it. This strategy was seen as essential for longer-term program sustainability and, eventually, commercialization.

With these developments emerging, microfinance came to be considered a potentially sustainable means of helping the poor, and it attracted widespread attention in the development community. Donor funding spurred global proliferation of microfinance institutions and pushed them to expand rapidly. In the race to achieve scale, outreach to poor and vulnerable groups became a secondary goal for many institutions. This change, combined with a shift away from integrated approaches, resulted in limiting the participation of the poorest groups, so that questions about the programs' impact on poverty arose.

The focus on scale and sustainability left little room in microfinance programs for young people. Group lending was directed to those with ongoing enterprises or other sources of income and experience in managing businesses. It required repeated borrowing and provided little or no grace peri- 


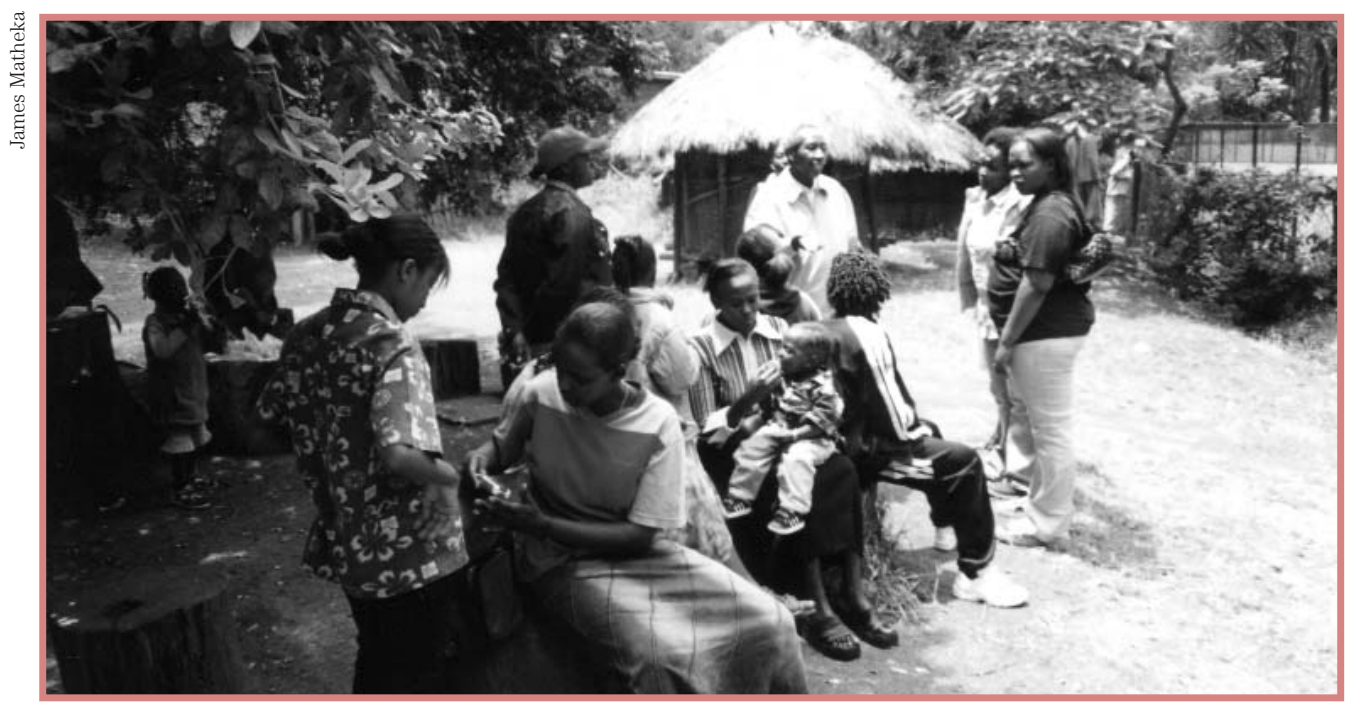

od for repayment. The minimalist approach offered little to prepare young people for productive economic participation and effective use of savings and credit.

The Late I990s:

\section{Diversification of Financial Products and Services for the Poor}

By the mid-to-late 1990s, group-lending programs began to exhibit weaknesses. Drop-out rates increased and growth rates leveled off or declined. Evaluations reflected large-scale outreach-particularly in Bangladesh — and relatively good repayment rates, but showed limited impact of the programs on borrowers. The proportion of poor and very poor clients declined in many programs. In most cases, credit played a role in supporting the protectionist strategies of the poor (mostly smoothing income and consumption) but was less effective in promoting sustained increases in enterprise, income, and assets. Debates arose as to whether women were truly empowered by microfinance. Moreover, although some programs achieved operational sustainability, few were financially sustainable or covering the costs of their capital. The experience of microfinance proved the "banka- bility" of the poor - especially women - in terms of their capacity to save, borrow, and repay loans. The standardized supplyled model appeared to fit some groups better than others, however.

Ultimately, innovators in the microfinance field shifted to a more demanddriven approach, emphasizing market research on the needs of clients and the diversification of products, services, and models. The focus of this approach was on addressing the requirements of poorer, more vulnerable clients and the "missing middle" of small enterprises that employed poor people who had remained outside the reach of formal financial institutions. In general, this change in strategy marked a shift from a narrow focus on microcredit for enterprise development to a broader one on financial services for the poor.

The demand-driven approach has encouraged innovation within the microfinance community among traditional MFIs and among other financial institutions such as credit unions, savings-and-credit cooperatives, and commercial banks. Moreover, it has also stimulated innovation among NGOs working with vulnerable groups. The demand-driven approach highlights the diversity of the poor and has given rise to greater flexibility in responding to clients' needs through a wider vari- 
ety of savings-and-loan offerings. Some of these include emergency loans, individual loans, and loans with longer or more flexible repayment terms and grace periods.

\section{The Early 2000s: Renewed Interest in Linking Microfinance to Broader Development Objectives}

As microfinance continues to mature in the 2000s, renewed interest has grown in strengthening the links between the strategy and broader development objectives. This interest offers an opportunity for experimenting with savings and credit for adolescents and young people. Approaches that combine microfinance with training, mentoring, and other forms of social support are still debated within the field. There is general agreement, however, that such approaches are important for supporting the effective use of credit and savings among vulnerable groups who have limited or no experience with formal finance.

\section{Group Lending Comes to Kenya}

K-Rep was one of the first organizations in Africa to promote microfinance as an approach to the alleviation of poverty. During the 1980s, K-Rep served as a support organization (funded by the United States Agency for International Development through a grant to World Education) for a network of NGOs and other community-based organizations extending credit to rural and low-income areas throughout Kenya. K-Rep worked with its partners to design the juhudi modelan adaptation of the Grameen Bank group-lending model. Support was provided to NGOs to replicate this model. With further USAID support, K-Rep initiated a direct lending program of its own in the early 1990s. Although small by Asian standards, it was one of the largest microcredit programs in Kenya, reaching
5,000 clients in the mid-1990s, and it became well known as a model in other parts of Africa.

K-Rep's original adult juhudi model consisted of self-help groups, formed by the participants, consisting of friends or acquaintances who felt they could collaborate with trust. After registering with the Kenyan Ministry of Culture and Social Services, the groups held weekly meetings with a K-Rep credit officer. The role of the credit officer is to conduct outreach and promotion of services, assess and admit new members, administer loans, and supervise group activities. Each credit officer ultimately oversees 350-400 members. Typically, credit officers have undergone training in business management or cooperative management.

The credit officer undertakes the training of the groups during the initial meetings. In the first two meetings, the officer discusses policies and procedures related to savings, loan applications and disbursements, repayments, arrears, defaults, and obtaining second and subsequent loans. In the following three meetings, the credit officer discusses leadership roles and the roles of group officials, meeting formats, members' rights and obligations, the administration and management of savings, record keeping, and the assessment of loan applications. During these first few meetings, group members are also contributing savings into a common bank account. Each week, each member deposits a mandatory minimum of 100 Kenya shillings (KSH) (about US\$1.30). Microloans are disbursed, usually after an eightweek period, and are extended to the member of the group who has saved at least 20 percent of the loan amount and who the group members consider to have a sound business plan. Group members are responsible for approving, adjusting, or rejecting a loan application, following the guidance of the credit officer. The mandatory weekly contributions continue even after the loan has been disbursed. The group savings serve as collateral for 
loans, with all group members effectively guaranteeing the loans of other group members. Loan repayment begins immediately, in the week after disbursement, with individuals repaying a proportion of their loans every week.

Planning beyond the mandatory collateral savings, many of the adult women use the opportunity provided by the group structure to save for emergencies or future goals. Once an adult group has registered with the Ministry and has established a group bank account, it establishes a second savings account to be used for emergencies, such as family illness, school fees, or in case business profits lag. The amount the women contribute to this second account is voluntary, and funds may be withdrawn at any time.

\section{The Emergence of Tap and Reposition Youth (TRY): Adapting the Adult Juhudi Model for Adolescent Girls}

TRY was a pilot scheme designed to adapt elements of the group-lending model to the needs of poor adolescent girls in the
Embakasi and Pumwani divisions of eastern Nairobi. These two divisions cover a large expanse to the east of the city's center and have a combined estimated population of more than 600,000 (see map below). Residents of Embakasi and Pumwani are mainly of the lower middle class and, increasingly, the urban poor. Within these two divisions, informal settlements dominate. The slum areas Shauri Moyo, Mukuru, and Majengo lie inside their boundaries. Roughly one of five residents of Embakasi and Pumwani live in these slum areas, and the proportion is growing. Most of the girls who participated in TRY came from these areas or from lower-class areas on the perimeters of the slums.

Although the TRY experiment was designed for the poor, the Kenyan clients faced radically different challenges from those that had been encountered by the clients of Asia's mass microfinance programs and the newer models in Africa. The group-lending model developed in Asia required substantial adaptation to make it relevant to young women in an urban African setting where HIV affects a substantial number of households in some way.

Adapting the group-lending model to target adolescent girls and women younger

\section{Figure I Location of TRY groups, Nairobi District, Kenya}

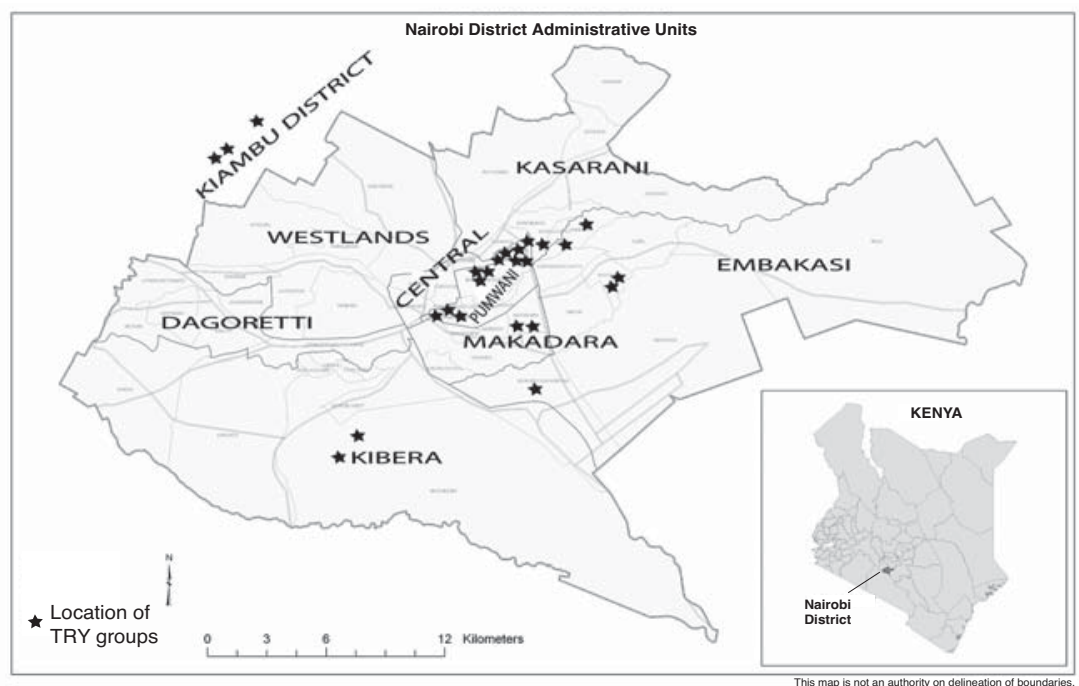


Table 2 Time frame of Tap and Reposition Youth (TRY)

\begin{tabular}{|c|c|c|}
\hline \multicolumn{2}{|c|}{ Year/month } & \multirow{2}{*}{$\begin{array}{l}\text { Major activities } \\
\text { Formation of Population Council (PC)/K-Rep partnership } \\
\text { Initial TRY pilot project (Phase One) designed, based on existing juhudi model for adult clients }\end{array}$} \\
\hline 1998 & Jan.-June & \\
\hline & July-Dec. & $\begin{array}{l}\text { TRY scheme publicized in Embakasi and Pumwani sections of Nairobi } \\
\text { Groups of girls begin to form }\end{array}$ \\
\hline \multirow[t]{2}{*}{1999} & Jan.-June & $\begin{array}{l}\text { Five groups formed and registered with Ministry of Culture and Social Services } \\
\text { Business training starts for more than } 100 \text { girls } \\
\text { Optional merry-go-rounds established among groups } \\
\text { Groups open savings accounts with Kenya Commercial Bank and begin weekly savings } \\
\text { First loans disbursed in June }\end{array}$ \\
\hline & July-Dec. & $\begin{array}{l}\text { Credit officer leaves for three months } \\
\text { Attendance at group meetings and loan repayments begin to drop }\end{array}$ \\
\hline \multirow[t]{2}{*}{2000} & Jan.-June & $\begin{array}{l}\text { Recruitment and loan disbursement suspended in January because of high drop-out rates and } \\
\text { poor repayment } \\
\text { Refresher training held for remaining TRY members } \\
\text { Loan disbursements recommence in April } \\
\text { Additional credit officer recruited }\end{array}$ \\
\hline & July-Dec. & $\begin{array}{l}\text { Attendance at meetings improves, as do savings and loan repayment } \\
\text { Evaluation of TRY Phase One undertaken by consultants }\end{array}$ \\
\hline \multirow[t]{2}{*}{2001} & Jan.-June & $\begin{array}{l}\text { Group meetings, savings, and loans continue } \\
\text { PC and K-Rep design TRY Phase Two, modifying approach, including boys, and expanding project } \\
\text { to a rural area } \\
\text { Additional credit officer recruited }\end{array}$ \\
\hline & July-Dec. & $\begin{array}{l}\text { TRY Phase Two begins } \\
\text { Recruitment and formation of new TRY groups begin (three groups formed) }\end{array}$ \\
\hline
\end{tabular}

2002 Jan.-June Members' drop-out rate high and loan repayments low

K-Rep introduces requirement that TRY clients provide adult guarantors for loans

Grassroots publicity intensified to offset slow recruitment

Some parents and community members suspicious of TRY project

Market research undertaken by PC and K-Rep to understand community's resistance

Baseline data collection for TRY Phase Two begins

July-Dec. Nine adult mentors recruited and trained; mentoring program begins

Three more TRY groups formed

2003 Jan.-June Market research undertaken in Kiambu, a rural area

Midterm review reveals that girls value mentors but that mentors and credit officers lack coordination

Rural arm of TRY begins; three girls' groups are formed in Kiambu

July-Dec. Identification cards for girls younger than 18 introduced, giving them access to some banking services Team-building workshop held

2004 Jan.-June TRY clients express demand for savings services separate from credit services Consultant identified to design savings program for adolescent girls Phase Three begins: savings-only clubs established open to girls aged 14-22 Following failure of using adult guarantors for loans, K-Rep introduces requirement that girls pledge assets to guarantee loans

July-Dec. Mobilization of Young Savers Clubs One credit officer assigned to oversee all Young Savers Clubs Data collection for endline survey begins. 
than 25 required innovative thinking and an experimental approach. At the time that the experiment was initiated, K-Rep's existing clients included virtually no girls in this age group; most were in their thirties or forties and married with children. In the initial phase, the project was open to girls aged 16-24; later it was adjusted to accommodate those aged 16-22. As the project progressed, it was altered to make it accessible to younger girls. To reach them, some of the economic criteria were adjusted, notably the minimum amount of savings required and the process of registration. The basic structure, procedures, and essential discipline of a microfinance program were maintained, however, as shown in Table 3.

Like the adult juhudi groups, TRY groups are self-selected. Fifteen to 25 members make up a group known as a KIWA (an acronym for the Kiswahili term kikundi cha wanabiashara, or "group of entrepreneurs"). The KIWA is registered with the

Table 3 Characteristics of the adult group-lending model compared with the TRY model of microfinance

\begin{tabular}{|c|c|c|}
\hline Characteristic & Adult savings and credit model & TRY savings and credit model \\
\hline Eligibility requirements & $\begin{array}{l}\text { Clients } 18 \text { and older } \\
\text { Currently operating a small business } \\
\text { or microenterprise }\end{array}$ & $\begin{array}{l}\text { Clients 16-24 (1998-2000); } \\
\text { Clients 16-22 (2001-04) } \\
\text { Interested in starting a business or currently } \\
\text { running a small business or microenterprise }\end{array}$ \\
\hline Fees & $\begin{array}{l}\text { Registration fee: KSH } 100 \text { (US\$1.30) } \\
\text { Passbooks: KSH } 65 \text { (\$0.85) }\end{array}$ & $\begin{array}{l}\text { Registration fee: KSH } 50 \text { (US\$0.65) } \\
\text { Passbook fee: KSH } 50 \text { (\$0.65) }\end{array}$ \\
\hline Group structure & Group of $25-30$, with subgroups of 5 & Group of $25-30$, with subgroups of five \\
\hline $\begin{array}{l}\text { Ratio of credit officer } \\
\text { to clients }\end{array}$ & $1: 350$ & $\begin{array}{l}1: 130(1998-2000) \\
1: 350(2001-04)\end{array}$ \\
\hline Training topics & Credit procedures & Credit procedures; business training, life skills \\
\hline Savings activities & $\begin{array}{l}\text { Mandatory savings as collateral } \\
\text { Merry-go-rounds (optional) }{ }^{a} \\
\text { Emergency fund for difficulty in repaying } \\
\text { loans/collapsing businesses }\end{array}$ & $\begin{array}{l}\text { Mandatory savings as collateral } \\
\text { Merry-go-rounds (optional) }{ }^{a} \\
\text { Voluntary savings (2004) }\end{array}$ \\
\hline $\begin{array}{l}\text { Minimum savings } \\
\text { requirement }\end{array}$ & KSH 100 (\$1.30) per week & $\begin{array}{l}\text { KSH } 50 \text { ( } \$ 0.65) \text { per week } \\
\text { (increased from initial minimum of KSH } 20 \text { per week) }\end{array}$ \\
\hline Access to savings & $\begin{array}{l}\text { Access to savings only on leaving program } \\
\text { Access to emergency fund only }\end{array}$ & Access to savings only on leaving program \\
\hline $\begin{array}{l}\text { Cash collateral required } \\
\text { for loans }\end{array}$ & $\begin{array}{l}10 \text { percent of loan (first loan) } \\
20 \text { percent (subsequent loans) }\end{array}$ & $\begin{array}{l}4 \text { percent of loan (1998-2000) } \\
10 \text { percent of Ioan (2001-04) }\end{array}$ \\
\hline $\begin{array}{l}\text { Noncash collateral } \\
\text { required for loans }\end{array}$ & Noncash assets pledged & $\begin{array}{l}\text { None (1998-2000) } \\
\text { Adult guarantor/pledging assets (2001-04) }\end{array}$ \\
\hline Loan size (first loan) & KSH 3,000-20,000 (\$39-260) & $\begin{array}{l}\text { KSH 3,000-15,000 (\$39-195) (1998-2000) } \\
\text { KSH 3,000-10,000 (\$39-130) (2001-04) }\end{array}$ \\
\hline Grace period & $\begin{array}{l}\text { Repayment begins the week after } \\
\text { loan disbursed }\end{array}$ & $\begin{array}{l}\text { Repayment begins the week after loan disbursed } \\
\text { (1998-2000) } \\
\text { Repayment begins two weeks after loan disbursed } \\
(2001-04)\end{array}$ \\
\hline Interest rate & 18 percent & 15 percent \\
\hline Repayment period & Three to 12 months & $\begin{array}{l}\text { Three to } 12 \text { months (1998-2000) } \\
\text { Three to } 9 \text { months (2001-04) }\end{array}$ \\
\hline Other services & Business advice (ad hoc) & $\begin{array}{l}\text { Business advice (ad hoc) (1998-2000) } \\
\text { Mentors provide counseling and training (2001-04) }\end{array}$ \\
\hline
\end{tabular}

${ }^{\text {a }}$ For a description of merry-go-rounds, see page 20. 
Kenyan Ministry of Gender, Sports, Culture and Social Services. Each KIWA is composed of three to five smaller groups called watanos (Kiswahili for "five"). Once registered, the KIWA elects its own officials, a chairwoman, treasurer, and secretary, and K-Rep opens a savings account in the group's name, which the members have selected. Unlike adult juhudi groups, however, most of the TRY self-help groups were not in place when the project started.

Most of the adjustments were of an economic nature, although some took into account the limited social capital of the girls. Because K-Rep was committed to managing the TRY groups in a professional manner and with the same rigor as with adult clients, it invested considerable time and effort helping clients to understand borrowing procedures and the importance of paying back loans. K-Rep emphasized that it was in the business of making loans and not giving handouts. In its first phase, TRY emphasized the credit and business aspects of microfinance over the savings and social aspects. As the program evolved, this balance shifted.

\section{Creating Awareness and Group Formation}

Once the basic program design and recruitment criteria were in place, K-Rep initiated awareness-raising activities in the Nairobi slums toward the end of 1998. Because adolescents and young women were an entirely new target group for $\mathrm{K}$ Rep, determining what outreach and promotional strategies would work was not possible at the beginning. K-Rep tried various strategies including public meetings and fliers, contacting churches and youthserving organizations, and promoting the project through K-Rep clients. K-Rep also tried to promote the project through City Council social welfare assistants who organize recreational activities for young people. Among these strategies, K-Rep found churches, youth-serving organizations, and social welfare workers to be effective channels for promoting the program and recruiting members. The trust the community placed in these institutions was an important factor. Surprisingly, the leasteffective strategy was promotion through mainstream clients. They shared the information about K-Rep, but mainly with their own family members and not with others.

K-Rep's good reputation was important in gaining support for the project from the girls' parents and from other community members. Legitimacy and trust within the community, helped to fend off negative rumors about the project. K-Rep's well-respected presence in the community, resulting from the success of its mainstream program, helped quash derogatory rumors before they had a chance to take hold. During the initial outreach period, community members repeatedly warned K-Rep staff that working with adolescent girls is challenging. The perception of many people was that adolescent girls are unstable, that they move in and out of communities, marriages, and relationships. Although they are motivated and energetic, they are often unclear about their personal or business goals.

In the initial months, K-Rep received 169 inquiries from girls interested in starting a business. Four months later, 130 girls had formed themselves into five groups, named their groups, elected group officials, and registered with the Ministry of Culture and Social Services. Being registered made the groups legal entities and allowed them to open savings accounts. The first group of recruits was older than had been anticipated; more than twothirds of the members were 20 or older. In other ways, the group members were a mixed lot; roughly half had only a primary education and half had a secondary education; two-thirds were single and onethird married; roughly half had children. Although 58 percent of the first group of recruits had ever worked for pay, only 29 percent were working for pay at the time of recruitment. One characteristic that may have differentiated girls who joined 
from those who did not was their confidence. The first girls interviewed at baseline were highly confident; 97 percent said they would not feel too shy to open a bank account, and 92 percent agreed with the statement that they could do things as well as most other people. ${ }^{4}$

In early 1999, during the group-formation process, K-Rep undertook weekly sessions to educate girls about credit policies and procedures. In March and April 1999, registered groups participated in a six-day training that covered business management and planning skills, entrepreneurial skills, life skills, and gender roles, among other topics (see Table 4). Two of these training days were devoted to life skills and discussion of social issues, and four days of the training were spent on business. Topics covered included identifying and planning a business, marketing, bookkeeping, pricing, and costing. Members were taught how to develop their own simple business plans, and KRep's savings and credit procedures were reviewed in depth.

\section{Starting to Save}

The juhudi model requires members to demonstrate a capacity to save prior to receiving a loan and to save on a regular basis after receiving a loan. By making small weekly payments, members demonstrate and develop financial discipline. The

Table 4 Schedule of TRY business and life-skills training

\begin{tabular}{|c|c|c|}
\hline Schedule & Objective & Topic \\
\hline \multicolumn{3}{|l|}{ Day one } \\
\hline Ice breaking & \multirow{4}{*}{$\begin{array}{l}\text { To help trainers better understand } \\
\text { participants } \\
\text { To allow participants to identify key } \\
\text { social problems and discuss strategies } \\
\text { for dealing with these problems }\end{array}$} & Introductions \\
\hline \multirow{3}{*}{$\begin{array}{l}\text { Dealing with social } \\
\text { problems }\end{array}$} & & Exercise on which keys open the doors to life \\
\hline & & $\begin{array}{l}\text { Personal problems facing young people (rape, } \\
\text { pregnancy, drug abuse) }\end{array}$ \\
\hline & & $\begin{array}{l}\text { Who should be blamed; how to avoid; where to } \\
\text { report; legal advice; girls' and boys' different roles }\end{array}$ \\
\hline \multicolumn{3}{|r|}{ ( } \\
\hline \multirow{2}{*}{$\begin{array}{l}\text { Social problems facing } \\
\text { young people } \\
\text { Changing attitudes about } \\
\text { nontraditional occupations }\end{array}$} & \multirow{2}{*}{$\begin{array}{l}\text { To create awareness of emotional change } \\
\text { To encourage girls to think about } \\
\text { nontraditional occupations }\end{array}$} & \multirow[t]{2}{*}{ Social and emotional change } \\
\hline & & \\
\hline \multicolumn{3}{|l|}{ Day three } \\
\hline \multirow{2}{*}{$\begin{array}{c}\text { Basic business } \\
\text { management }\end{array}$} & \multirow{2}{*}{$\begin{array}{l}\text { To raise awareness of the importance of } \\
\text { building a business from a stable base }\end{array}$} & How to start a business \\
\hline & & $\begin{array}{l}\text { How to obtain necessary information about a } \\
\text { business }\end{array}$ \\
\hline \multicolumn{3}{|l|}{ Day four } \\
\hline Bookkeeping & To encourage girls to keep simple records & Tools for measuring profits \\
\hline \multirow[t]{2}{*}{ Feasibility study } & \multirow{2}{*}{$\begin{array}{l}\text { To encourage girls to obtain information } \\
\text { about a business before starting it }\end{array}$} & The double-entry system \\
\hline & & Practice in making entries \\
\hline \multicolumn{3}{|l|}{ Day five } \\
\hline $\begin{array}{l}\text { Costing and pricing } \\
\text { Marketing (the six P's: }\end{array}$ & \multirow{3}{*}{$\begin{array}{l}\text { To learn the importance of costs and } \\
\text { of calculating profits } \\
\text { To learn the importance of marketing } \\
\text { and its different elements }\end{array}$} & \multirow[t]{3}{*}{$\begin{array}{l}\text { Gathering information on materials, markets, } \\
\text { skills, funds, costs, legal requirement, and risks }\end{array}$} \\
\hline $\begin{array}{l}\text { people, product, price, } \\
\text { promotion, place, and plan) }\end{array}$ & & \\
\hline Budgeting & & \\
\hline \multicolumn{3}{|l|}{ Day six } \\
\hline Business planning & $\begin{array}{l}\text { To learn the importance of business } \\
\text { planning }\end{array}$ & Monthly financial planning \\
\hline
\end{tabular}

Source: Sebstad (2001).

\footnotetext{
${ }^{4}$ The authors do not have comparable data for girls in Nairobi who did not join the program, so cannot conclude that TRY girls were more confident than others. When similar questions were asked in other surveys of adolescents, however, the proportion of girls demonstrating such confidence and self-esteem was far lower.
} 
funds they save provide a reserve for the group to draw upon in case a member falls behind in repaying her loan. These savings are linked to the loans and cannot be withdrawn until the member leaves the program. By May and June 1999, the members of all five groups had paid their registration fees and the fees for passbooks (which are used to record their savings, loan-repayment amounts, and balance) and had started weekly savings.

Savings accounts were opened at Kenya Commercial Bank..$^{5}$ The cost of opening the group savings account was KSH 1,000 (\$13), a cost shared among the girls. Initially, girls were asked to save KSH 20 (\$0.26) per week, but that amount was soon increased to KSH 50 (\$0.65) at the girls' request. Diagnostic research showed that 52 percent of girls in the first intake of TRY already had savings; they had saved an average of KSH 470 (\$6.10) each. Seventy percent of these girls stored savings at home. They described the difficulty of finding a safe place in which to keep their savings. Many had to hide the money from their husbands and boyfriends. Perhaps their appreciation for being able to gain access to a bank account through membership in TRY is reflected in their enthusiasm for saving. Weekly savings is an ongoing requirement of TRY membership, and according to the initial design of the program, girls could access their savings only when they withdrew from TRY.

\section{Merry-go-rounds}

The need for a savings model was apparent from the beginning. At the outset, the girls expressed interest in the spontaneous establishment of "merry-go-rounds" to provide emergency capital while they remained in the group. The merry-gorounds gave them some independence
Table 5 Timeline of TRY activities after a savings group is formed

Month Activity

$1 \quad$ Group begins application process for registration with Ministry of Culture and Social Services Members select a name for the group

Group meets weekly and credit officer discusses K-Rep procedures

Members may start merry-go-round

2 Members await registration and continue to get to know each other

Credit officer continues discussion of procedures Group continues merry-go-round

3 Once registered (after three-to-six-month waiting period), members elect their officials Savings account is opened in the group's name Members purchase K-Rep passbooks Members begin mandatory savings

$4 \quad$ Members receive business and life-skills training (six days)

Members begin to prepare business plans and loan applications

5 First loans may be disbursed (to two of five group members)

Repayment starts immediately (the following week in the pilot phase)

6 Two more members may receive loans if first two beneficiaries make timely repayments

Savings, repayments, merry-go-round continue

7 Last member of watano receives loan, if first four beneficiaries make timely repayments

Savings, repayments, merry-go-round continue

8 Savings, repayments, merry-go-round continue

9 Savings, repayments, merry-go-round continue

10 Savings, repayments, merry-go-round continue

11 First loans are repaid; members may apply for a second loan

12 Second-round loans are repaid; members may apply for a third loan

13 Third-round loans are repaid; members may apply for fourth loan

and power over their savings. While they waited for completion of the formal registration of the group with the Ministry of Cultural and Social Services, typically 15 of the 20 girls in each group would decide jointly to start a merry-go-round

\footnotetext{
${ }^{5}$ Accounts were opened initially at Kenya Commercial Bank because K-Rep Bank had not yet been established when the TRY project began. TRY accounts have been managed at the K-Rep Bank since it opened in December 1999.
} 
whereby every week, members contribute an agreed-upon sum to a kitty, and girls receive the amount in the kitty in turns. The amount TRY members decided to contribute was between $\mathrm{KSH}$ 20 and KSH 50 per week. A girl who participates in a merry-go-round of 15 girls who each make a weekly contribution of KSH 20 will receive a lump sum of at least KSH 300 (\$3.90) every 15 weeks. The sequence of the kitty's recipients is determined by picking numbers out of a hat. Girls often used the merry-gorounds as occasions for social events. In some groups, girls would leave the weekly TRY meeting and convene at the home of that week's merry-go-round recipient. The recipient would serve tea and snacks, members would socialize, and the recipient would be given the money in the kitty. Girls often used the kitty funds for a purchase such as shoes, clothing, or household linens that they could not have made without having a considerable sum of money on hand. ${ }^{6}$ Girls were willing to invest their scarce funds in opening a commercial savings account, they requested an increase in the savings contribution, and many started merrygo-rounds, all of which reflect their interest in and commitment to saving.

\section{How Group Meetings Took on a Life of Their Own}

The TRY groups met weekly. Group members or the credit officer arranged meeting places, often a community social hall or church meeting room that could be made available to the girls. Eventually some groups met at a member's business premises, such as one girl's hairdressing salon. A few groups were compelled to pay for meeting space. One group paid a restaurateur KSH 150 (\$1.95) per month

\section{The TRY Group Meeting}

- Group members and credit officer assemble at meeting place.

- Chairwoman calls the roll.

- Girls give their weekly savings amount to treasurer who records the amount in the member's individual passbook and in the group's savings register.

- Girls who have taken out loans make their repayments to the credit officer, and the amounts are recorded in the borrowers' passbooks and in the group's register.

- Credit officer confirms amounts recorded in registers and passbooks.

- Matters such as absent members, potential defaulters, and the reinforcement of credit policies, are discussed.

for the use of his restaurant. To the extent possible, members attempted to find meeting places that were convenient to girls' homes or workplaces.

The period in which the initial meetings take place before loans are disbursed is termed the "countdown" period and usually lasts for eight weeks. The meetings, usually one to two hours long, are opportunities for loan policies and procedures to be reinforced and for group members to become acquainted with each other and the loan officer. The group chairperson presides over the meetings, the treasurer receives and records all savings, and the credit officer oversees and advises members about the microfinance process.

The weekly meetings became a sort of ritual for members, and the groups soon devised their own rules to promote cohesion and discipline. For example, if a member arrived late for a meeting, she was required to pay a small fine, KSH 5 to KSH 10 (\$0.07 to \$0.13). Money collected

\footnotetext{
${ }^{6}$ In his essay The Poor and their Money (2000), Rutherford discusses the importance of savings in the lives of poor people. He describes saving up, saving down, and saving through as ways in which poor people turn small savings into lump sums to meet life-cycle needs, deal with emergencies or unexpected expenses, and take advantage of opportunities that occur.
} 


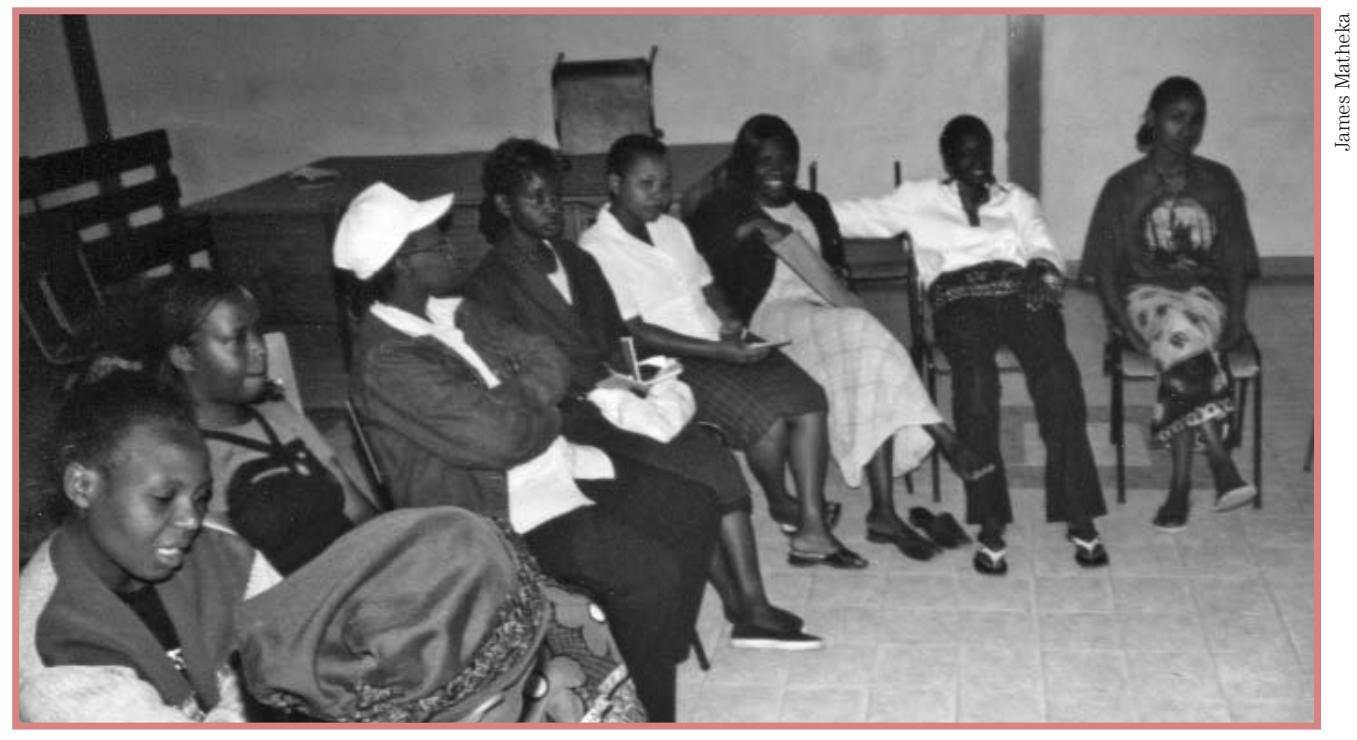

in fines was put aside and used for transportation to the bank to deposit the group's savings. Every week two girls were given the opportunity to visit the bank, a new experience for most members that became an important event in their lives. Girls would look forward to their assigned bank day and wear their best clothes (a common practice in Kenya when visiting places away from home).

For many girls, the group meetings also became an occasion for sharing personal experiences and troubles. They held conversations about their relationships with partners or with parents. As the project progressed, the value girls placed on being part of a group became clear:

My knowledge enabled me to sit with [an aunt dying of AIDS] at such times and just listen, offer her words of encouragement and pray with her. Even when she was very sick, I was the only one who was free to take care of her basic needs, like cleaning her. What I have learned here from [the group] has also helped me and made me a much stronger person when I am faced with such a situation. . . . At least I feel that I added quality to her last days, because she had sunk into a depression and lost a sense of dignity and self worth. I gave her moral courage and the heart to go a little bit longer. When you are in a seminar being taught all these things, you do not realize their importance, but when you are in such a situation and you actually find yourself applying them, that is when you realize just how helpful it is.

\section{-Focus-group participant, age 29, married, ten years of education}

For my part, I enjoy the boosting we give each other, be it in terms of solving social problems, business issues, or helping each other out with family or marital problems. Since I joined the group, I have acquired a number of friends with whom I share problems or with whom I just have fun. I don't feel lonely.

-Focus-group participant, age 22, divorced, eight years of education

For most of these girls, the groups became their only source of social contact and support. When a girl was experiencing a problem or major event in her life such as childbirth, group members would come together to provide support. In one case, a girl needed medical care, and group members assisted her in finding a clinic that could treat her ailment. The girls went together to lend her moral support and helped to pay the cost of the medical care. When another member 
gave birth, group members held an informal baby shower where they gave the new mother basic items for the baby. The credit officer, a young woman in her late twenties, came to function as a mentor and was the only older confidante many of the participants had. She became a friend with whom they shared their concerns and experiences; she offered them a sympathetic ear and often gave them advice and moral support. As the program evolved, increasing pressure was placed on credit officers to act in opposition to their role as a friend when they had to urge the girls to save regularly and repay their loans.

\section{Starting to Take Out Loans}

The first loans were granted in June 1999 to the best-prepared girls a few months after the first group began saving. Within each group, the subgroups, or watanos, decide which two of its members receives the first loan disbursement. The five subgroup members negotiate, and the choice of recipients is consensu-

\section{Business Examples from TRY Loans}

- One member opened a hairdressing salon in Huruma slum (age 24; never married; currently on her second loan)

- One started a fruit-juice business in Majengo slum (age 25; never married)

- One built a housing structure for rent (age 29; married; recently has expanded her business ventures to include a telephone business; currently on her third loan)

- One expanded a meat-selling business in Huruma (age 23; divorced)

- One started buying and selling firewood in Mathare slum (age 23; never married)

- One started a secondhand clothing business in Majengo (age 25; married; currently on her second loan) al. The decision to grant a loan is based on how members view individual girls' preparedness for their enterprises based, in part, on the business plans that they have developed and the likelihood that they will be able to meet their repayment requirements. In the first phase of TRY, repayments began the week following the receipt of the loans. If the first two recipients made weekly repayments for a month, the second pair of group members were granted their loans, and if all four recipients made repayments for an additional month, the final member of the group received her loan.

By the end of the first phase of TRY in December 2000, 132 loans had been granted, of which 26 were second loans. About two-thirds of recipients used their loans to start new businesses; the remaining one-third expanded existing enterprises.

\section{Limits of the Initial Microcredit Model in the Context of Girls' Multidimensional Vulnerability}

Traditionally, microfinance institutions measure the success of their savings and loan groups according to repayment rates, retention rates, and expansion of loan activity achieved as more members move from taking out small loans to requesting larger ones. For a microfinance institution, granting a great number of loans, charging interest, and insuring high repayment rates are the basic mechanisms by which they finance their operating costs and achieve sustainability. From the outset, K-Rep and the Population Council recognized that repayment discipline was essential to sustainability but that it was not the only indicator of success. The two agencies were also determined that the program would make a real difference in the lives 


\section{Expanding TRY to Rural Areas}

In June 2002, K-Rep and the Population Council began to expand the TRY experiment to one rural area, Kiambu, about 22 kilometers (13.6 miles) from Nairobi in Central Province. Before establishing the program, staff from K-Rep and the Council took part in a six-day training session on market research, focus-group discussions, and participatory rapid appraisal provided by a consultant to K-Rep with experience conducting microfinance research in Asia and Africa. K-Rep and Population Council staff perceived these techniques as useful, in light of the previous challenges they had experienced in recruiting participants and forming groups in Nairobi. Ultimately, KRep and Council staff undertook a needsassessment in Kiambu to clarify the financial requirements of the community, mechanisms to reach adolescents, and ways of gaining the confidence of the community and of parents. The main findings were that few people in this rural area had access to formal financial services and used informal means of borrowing money, such as asking for loans from shops or friends. The support and involvement of parents and of community leaders was seen as critical for programs designed to help young people. In February 2003, K-Rep staff partnered with chiefs and subchiefs in Kiambu and with church leaders in undertaking outreach and promotion activities. A baraza (community meeting) was called in which K-Rep staff, chiefs, and religious leaders promoted the program among community members and adolescents. More than 100 girls attended the meetings where they had the opportunity to ask questions publicly about the program concerning how to go about obtaining loans, who qualifies for the program, where the money for the loans comes from, why only girls are involved, and who keeps the money the girls are saving. One credit officer was assigned to follow up and form interested girls into groups. Although based in Nairobi, the credit officer initially traveled to Kiambu every day to bring groups together and encourage discussions. Ultimately, three groups consisting of 20 members each were formed. The members held their meetings at the chief's camp in two locations. In the Kiambu pilot, the drop-out rate is low and repayment rates are 85 percent, higher than those of the KDA urban program. In this rural area, the girls' mobility is limited, so that defaulting on a loan or disappearing is difficult. They have a small, close-knit community to support their economic participation. Some of the businesses started by the girls in the rural experiment include selling animal fodder, selling sawdust and firewood, raising and selling poultry, working at animal husbandry, selling telephone services, selling secondhand clothes, and running retail shops. of the adolescent girls and young women who were its beneficiaries.

Once the loans were disbursed (starting in June 1999), repayment rates were high at first but began to decline after Christmas 1999 (see Figure 2). When a few group members began to fall behind in their payments, discipline broke down in some of the groups and the problem spread. By March 2000, repayment rates had fallen to below 80 percent and girls began to drop out of the program. ${ }^{7}$ The agencies first identified payment and drop-out problems as related to conditions in group members' businesses, to unexpected emergencies or financial demands, to the seasonal demands of Christmas, ${ }^{8}$ and to members' inexperience in managing the use and repayment of loans. The management side of the credit component was also not as strong as it should have been. The waiting time between formation of the groups and disbursement of the loans was excessiveseven months for some participants. Turn-

\footnotetext{
${ }^{7}$ The standard for a good credit program is to maintain a repayment rate greater than 95 percent.

${ }^{8}$ A typical expenditure pattern in Kenya is high during the Christmas season with low consumer demand in the months thereafter.
} 


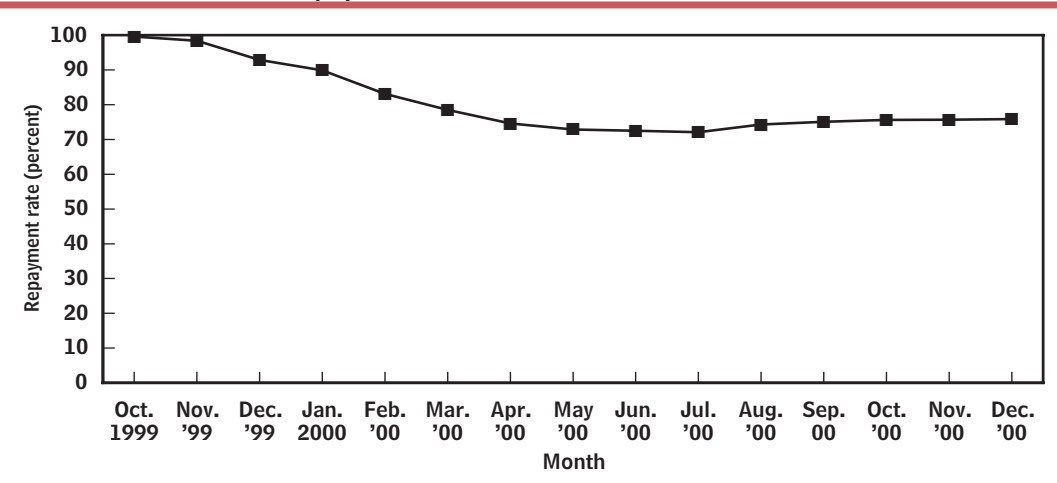

Note: The qualitative repayment rate is defined by K-Rep as: Amount paid - amount due /amount due (cumulative amount).

over of members was high, causing further delays and greater cost.

Ultimately, repayment problems and the high drop-out rate were largely related to the mismatch of the project's design to the target group. The model's heavy emphasis on credit and limited social intermediation or support, was inadequate for less experienced and more vulnerable girls. For more experienced girls, loan repayment was not so great a problem. For them, the size, the terms and conditions, and cost of the loans were not problematic. Younger, more vulnerable girls were more likely to have difficulty meeting the program requirements, however; they required additional support that was not offered and eventually dropped out. At the endline survey, girls who had dropped out of the program were found to be younger, less educated, less likely to live with a parent, and poorer than girls who were still in the program. Nearly one-fourth of those who dropped out (23 percent) were younger than 20, compared with only 4 percent of the remaining TRY clients. Although 18 percent of TRY dropouts had not completed secondary school, only 10 percent of the remaining TRY members had not done so. Moreover, although 47 percent of TRY dropouts were rated "low" on a household economic scale, 35 percent of the girls who remained in the program were in this category. The early period of the TRY project suggested that a critical need existed among many of the participants for social support and for training to complement group lending, and this part of the project expanded in subsequent phases.

Another issue identified later was the inaccessibility of compulsory savings. In retrospect, the girls had not received a clear-enough explanation that they would not have ready access to the money they saved and that, in effect, savings were locked away from them for the duration of their participation in the program. As a result, some of the girls dropped out of the project either because they needed their savings or because they were unsure about the security of their saved funds. Many girls had made clear their need for a safe place to keep their savings during the diagnostic study of the pilot phase.

Sometimes I do not want my husband to know that I have money, so I take it to my female friends to keep for me.

-Focus-group participant quoted in Erulkar and Khan (1999)

Another study showed that a considerable number of girls were already saving when they joined the project. Sixtythree percent of girls who were working had savings, and 47 percent of nonworking girls also had savings. Seventy per- 
cent of savers kept their money at home. In light of some of the challenges of introducing a voluntary savings component, this information was not acted upon until much later in the program.

Thus, the program's social-performance objectives of increasing girls' security and financial assets conflicted with its financial-performance objectives focused on credit and loan repayment. Although some girls struggled to remain in the TRY groups, others dropped out. K-Rep also was struggling with the experiment, and in 2000 it temporarily suspended loan disbursement to evaluate the reasons for declining repayment, dropouts, and noncompliance among some group members. This suspension of services was a standard K-Rep practice, but in this process, the girls who had repaid their loans and were waiting for a second loan were punished along with those who were delinquent.

Without understanding the full extent of the problem, staff decided to provide refresher training. Most of the 57 girls who attended this training represented those who were already committed and better prepared to take repeat loans. In addition to business planning and management, the training addressed a variety of issues including the social challenges facing adolescents. Although the sessions dealing with social issues were appropriate for girls at all levels, those covering business planning and management were designed for better-prepared girls. During this first phase, however, the model remained primarily one of credit with only limited emphasis given to savings and none given to social mentoring, financial education, or other activities appropriate to a broad spectrum of adolescent girls, and especially to the most vulnerable.
Building on these lessons, both K-Rep and the Population Council felt that if additional adjustments were made to the existing group-lending model so that TRY provided additional social support, the program could achieve a sustainable balance. Even successful adult programs that have helped participants to establish businesses, to gain experience in handling and managing money and work in groups, and to create a friendship network in their homes or work locations, need periodical adjustments. Designing a microfinance model for adolescents was a new experience for everyone involved. Despite its early problems, the program benefited from K-Rep's mandate for innovation and openness to further experimentation.

\section{Who Are the TRY Girls? Linking Vulnerability to HIV Risks}

The stories of the TRY girls parallel the stories of girls in many other developing countries in the grip of the HIV pandemic. In Kenya's urban settlements, girls suffer rates of HIV infection that are two to six times higher than those of boys of the same age (see Table 1).

The baseline information gathered when girls entered the project revealed the extent of their vulnerability and that risky sexual relations are often not under their control. ${ }^{9}$

As noted above, more than two-thirds of the TRY girls were older than 20 , so the finding that 85 percent were sexually experienced is not surprising. Among girls in that category, the vast majority first had sex with a boyfriend (86 percent) or a husband (8 percent). These partners were often substantially older; husbands, on average, were 6.4 years older than their wives, and boyfriends were 4.4 years older than their partners.

\footnotetext{
${ }^{9}$ Baseline surveys were conducted among girls entering the TRY project and among controls matched on the basis of residence, age, education, marital status, and childbearing status. In all, 834 girls were interviewed, half of whom were TRY participants and half of whom were controls. In the context of the interview, a limited number of open-ended questions were included, and interviewers were trained to probe and take down responses verbatim. Data presented in this section are based on responses of both the TRY girls and the controls, unless otherwise noted.
} 


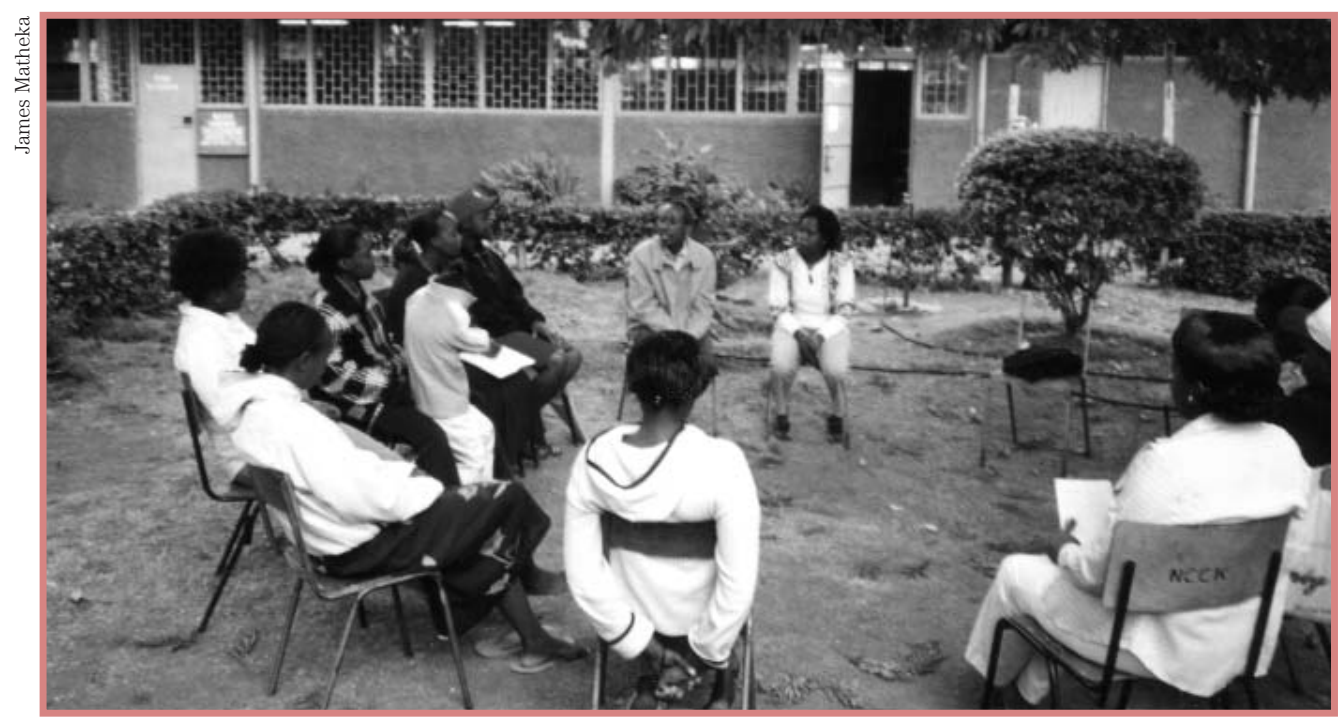

The experience of first sex was often unwanted and beyond the girls' control. Only 37 percent of the girls surveyed reported that their first sexual experience was voluntary. Nineteen percent did not want to have sex and 44 percent were undecided about having sex at that time. Forty-five percent of sexually experienced girls reported that their first sex occurred when the boy or man would not take "no" for an answer, reflecting the decisionmaking power that older partners have over these young women. Moreover, 8 percent of the girls reported that the boy or man threatened them, and 15 percent said that they were coerced. Indeed, the survey findings reveal how girls' experience of sex is often linked to a sense of danger and powerlessness.

I have a brother whom I used to stay with. He used to come home drunk and beat us. So that night, I ran out and met this guy who offered me accommodation.

-Age 20, never married, six years of education

He asked me out. When we went, I think he drugged my soda, because I got drunk and later found myself in his house bleeding.

—Age 17, never married, eight years of education
He cheated me to [get me to] stay at his place until late and told me nothing would happen. When I wanted to leave finally, it was too late. Our gate was locked, so I had to spend [the night] with him, and we had sex.

-Age 20, never married, nine years of education

My friends asked me to visit them, and when I went, they had arranged with some people who would take my virginity away.

-Age 22, married, nine years of education

In findings similar to those of the 1998 Kenya DHS (NCPD 1999), 24 percent of girls interviewed in the baseline study were promised money or gifts in exchange for sex, a finding that underscores the links between the girls' economic vulnerability, their experience of unwanted sex, and their risk of acquiring HIV.

He told me that he had a surprise for me in this house - that he had bought me a dress. When we reached [the house], I found there was no dress for me and he insisted that it was time that I showed him that I truly loved him by having sex with him.

-Age 19, never married, six years of education 
I was still in school, and he asked me to pass by his place for a soda. Then when I got there, he made me have sex before [we had] the soda.

—Age 24, married, 11 years of education

Often when girls feel that their relationship with a man involves a risk of acquiring HIV, they are not able to end the relationship. Thirty-seven percent of the girls who were having sex with either husbands or boyfriends reported anxiety about their relationships and a desire to end them. Sixty-nine percent of girls did not know the HIV status of their partner, and one-fourth of these wanted to leave the relationship fearing that their partner would give them HIV. Only a minority of girls who were afraid of acquiring HIV had found a way to leave a risky relationship. Most spoke of a reluctant reconciliation that was linked to economic dependence:

[I didn't leave because] I didn't know where to start . . . because I didn't have money, and I had the children to take care of [and] no home to go to.

-Age 20, married, three years of education

I had nowhere to go, and all men are the same. I decided to be patient and pray a lot.

—Age 20, married, eight years of education

Girls' social networks and families offered no supportive alternatives. Living in a densely populated urban slum, the TRY girls were, nevertheless, isolated. Only 12 percent lived with both parents. More than half (56 percent) of the girls interviewed at baseline disagreed with the statement, "You have many friends in your neighborhood." Their lack of social support can be attributed, in some cases, to their migratory status: More than half (52 percent) had migrated to the area, and of these, a high portion (43 percent) had come to the city in search of jobs. HIV/AIDS is a daily presence in their lives: 82 percent of the girls reported knowing someone who had died of AIDS, and 28 percent had experienced the death of a family member from AIDS.

\section{Expanding Social Support within a Microfinance Program}

K-Rep and the Population Council revisited the question of offering social support. Although borrowing was a central interest of TRY participants, most girls also expressed an interest in establishing savings and friendship networks and learning skills. An opportunity to meet people, make friends, and benefit from training clearly was valued by participants.

[Most of all,] I liked the seminars and then interacting and socializing with members of the groups. The seminars taught me a lot, especially about HIV/AIDS.

—-Age 17, never married, eight years of education

I like seminars. If it were not for K-Rep, I wouldn't have attended so many seminars, or even any. I had not attended any seminars before I came to K-Rep.

-Age 19, never married, seven years of education

The integrated design of the program required credit officers to function as mentors and confidantes and simultaneously as enforcers of credit policies. Group lending was structured in such a way that members, who, initially, were newfound friends, eventually were pressuring each other to repay their loans on time. Thus, the model was generating new social costs; it created tension when new friendships were undermined by the requirements of loan repayment and also from the complicated relationship with credit officers in their dual roles. More- 
over, for a substantial number of girls, the locking up of their savings as group collateral for loans generated distrust, causing disagreements with credit officers and among group members. For those especially vulnerable girls who were not ready to take part in a formal credit scheme, the TRY groups could not function both as effective microfinancedelivery vehicles and as an opportunity to build friendships, support networks, and alliances.

The reasons for the high drop-out rate were economic and social: unstable group dynamics, quarrels with mentors, quarrels with other members, and the inability to borrow or save or in accordance with TRY rules. Originally, the girls gave the economic factors - the savings and the lending requirementsmore weight than the social factors. Later, the tension over the rigidity of group-savings requirements, the pressure to continue to borrow and maintain repayments, and the shame experienced by girls who came to meetings without the money required for savings contributions or loan repayments forced many girls to drop out of the project. The less vulnerable and more committed girls had their own frustrations. Those who wanted to take another loan were forced to wait for others who were not repaying their loans rapidly enough, and this interdependence between the most vulnerable and the less vulnerable (sometimes playing out as younger versus older girls) undermined the cohesion of the groups that was the main benefit of TRY to many of the participants.

\section{Adding a New Cadre of Mentors}

The fragile balance between the social function that the credit officer played and the economic performance of the groups became clear late in 2000 when a credit officer who had been overseeing the girls' savings and credit groups took a leave of absence to attend a training course overseas. During her absence, loan disbursements were temporarily suspended, and the credit officer was replaced temporarily by another officer with whom the girls were unfamiliar. By the time the original credit officer took her temporary leave, the weekly groups had taken on a life of their own with her leadership at their core. Group activities tended to revolve around her; group meetings would not start until she had arrived, and her opinions and guidance were highly valued. During her leave, many of the groups had trouble managing meetings for lack of consistent leadership, and dynamics within the groups were often poor. Girls began to miss meetings, and many left the program.

The experience of declining participation linked to the absence of the credit officer, highlighted the importance of mentoring and the opportunities for social support that the weekly meetings provided to girls living in the slums.

At this point, K-Rep and the Population Council decided to offer additional social support mechanisms to the girls participating in TRY. This decision was not wrong so much as it was inadequate. The two agencies believed that what was required was finding the right support formula and separating the role of credit officer from that of mentor. They agreed to establish a dedicated cadre of part-time staff mentors to work in parallel with the credit officers.

The notion of adding mentors made a good sense, but it overlooked the girls' expressed need for a means of saving money. The evaluation report suggested strengthening social support by incorporating formal savings schemes and merry-go-rounds delinked from borrowing. The recommendation suggested strengthening social support mechanisms with savings options as follows: 
Mutual support and development of reciprocal social networks-This could involve add-ons to weekly meetings for the Kiwas (25 girls); and monthly meetings open to members of three or four Kiwas in neighboring areas (say 100 girls).

For the weekly social support meetings, group members could opt to stay on after the credit/savings collection to participate in a wider set of activities. The TRY field officer or voluntary community/social workers could be trained to facilitate group discussions and to engage girls in participatory learning activities on relevant topics. A number of participants have expressed a desire to start weekly merry-go-rounds within their groups, and this could be an addon activity.

TRY also could organize monthly issues meetings to encourage the development of wider reciprocal social networks among the girls. The opportunity to meet and interact with a larger social group, make new friends, and develop new business and social contacts could provide the basis for new social networks ('social assets'). The meetings could be organized in various ways. They could involve a presentation or discussion around a particular topic. They could involve business 'mentors,' experts in the health or legal field, or a topic selected by the girls themselves to discuss as a group. The idea would be to extend the range of activities for TRY participants. The monthly meetings could provide a vehicle for additional training, and a mechanism to raise awareness on critical social issues, problem solving strategies, outside sources of support for dealing with certain problems (social services, legal services, etc.). They also could encourage mutual support and sharing. Some of the issues meetings also could involve parents, partners, or other family members of the girls. (Sebstad 2001: 24-25)

In deliberations about the profile of the mentors, the Population Council and K-Rep reviewed the variety of issues credit officers had been called upon to address. These included health-related issues (reproductive health and HIV/ AIDS), and issues concerning managing intimate relationships, expanding businesses, finding new learning and teaching opportunities, and resolving conflicts in friendships and in the community. The agencies decided that mentors should be drawn from a variety of backgrounds, and the posts were advertised in the Daily Nation, one of the most popular newspapers in Kenya. More than 900 applica-

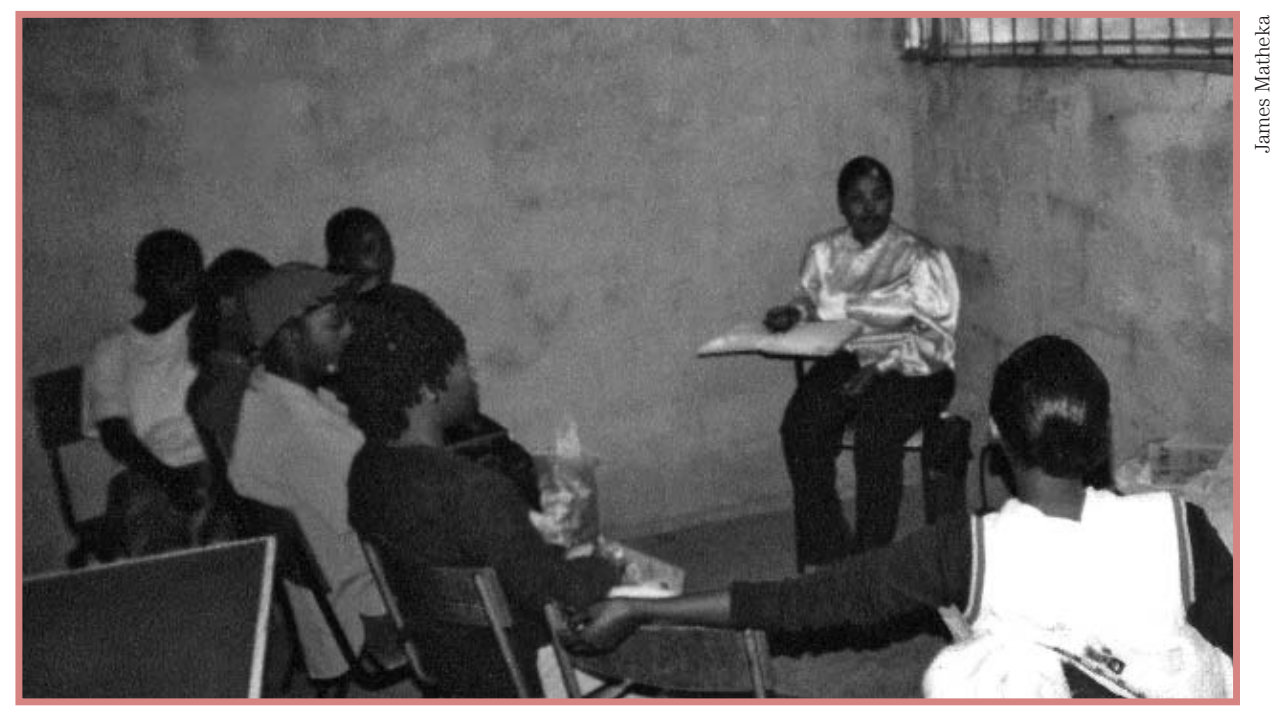


tions were received, and 34 candidates were interviewed by a panel that included K-Rep and Population Council staff. The professional backgrounds of the nine mentors that were selected were varied, as were their educational backgrounds. Some had university degrees and some had attained only a primary education. One of the mentors was a longstanding K-Rep client who had built a successful dressmaking business with K-Rep loans. Mentors were hired as part-time contract workers at a monthly salary of KSH 8,000 (\$104), roughly the full-time wage of a primary-school teacher in Kenya. This salary was offered so that attrition of trained mentors would be kept to a minimum and productivity sustained. ${ }^{10}$

The mentors underwent an initial four-day training that included an overview of the TRY program, a session on adolescence in Kenya, and sessions on reproductive health and family planning, HIV/AIDS, relationships, leadership skills, facilitation skills, conflict resolution, record keeping, social service agencies in Nairobi, and developing work plans. Because the mentors were expected to complement credit officers, they received an orientation on the savings and credit procedures of the TRY project. As part of the orientation, the mentors compiled a list of referral services including health, legal, and social services that could be used to assist TRY girls who needed help that was beyond the scope of the project.

The nine mentors were grouped into three teams to maximize their skills. A team generally consisted of one mentor who had strong business skills, one who had a strong background in public health, and another with social work or community-development skills. The three teams were each assigned six TRY groups, or a total of about 90 to 120 girls, for whom they would have primary responsibility, on the understanding that all TRY girls would have access to any and all mentors. Mentors first conducted simple needsassessments among the girls in their groups for which they explored the issues that were most important to the girls and the types of activities that interested them. Across all groups, the primary issue about which the girls sought more information and support was HIV/AIDS.

Following the needs-assessment, the mentors devised an agenda of activities based on the expressed requirements of their groups. Girls met every week, normally after K-Rep had finished its savings and credit activities. Among the activities on the agenda were group discussions, educational sessions, recreation, excursions, and sports and fitness activities. Most often, these activities were held following the TRY group meetings, but some were scheduled at other times. As a group, the mentors and credit officers also periodically organized educational seminars at which all TRY participants came together for information and discussions with guest speakers. Topics of these seminars have included HIV/AIDS, domestic and gender-based violence, women's rights, drug and alcohol abuse, male-female relationships, and family planning. In the seminar on HIV/AIDS, information was presented about voluntary counseling and testing, nutrition in HIV management, mother-to-child transmission, and antiretroviral therapy.

The initial experience with the mentors has shown that they can offer girls urgently needed social support including help with managing the challenges and risks of male-female relationships. The girls reported their deep appreciation of the mentors, and the mentors' presence clearly helped group cohesion and boosted attendance at the meetings.

\footnotetext{
${ }^{10}$ For details of another example of using salaried community-based workers rather than volunteers, see Erulkar et al. (2004) for a description of the Nyeri Youth Health Project.
} 
I enjoyed the jokes and fun we used to share. We used to talk and discuss issues about boy-girl relationships and how to deal with men. [The mentors] were very open and friendly with us.

-Age 25, married, 12 years of education

[The mentor] was like a mother figure. She advised us on life issues, relationships, and how to cope with crisis situations in our lives and with our boyfriends and husbands.

-Age 27, unmarried, 12 years of education

The girls' response to the mentors was enthusiastic; the mentors' presence was taken as a sign that K-Rep cared about group members personally and was not interested only in providing financial services.

Initially, in a few cases, tension arose between credit officers and mentors. Whereas the mentors were engaged to provide girls with support and advice and express understanding of the girls' experiences, the credit officers had to enforce loan repayments. The two cadres of staff were intended to work side by side with the TRY girls, but sometimes they found themselves at odds, especially when mentors attempted to mediate between credit officers and TRY girls in negotiating delays in loan repayments. A four-day team-building workshop was held to forge a better understanding of the contrasting (and potentially overlapping) responsibilities of credit officers and mentors and to expand their understanding of what the girls felt to be most important. Topics of the training sessions included problem solving, conflict resolution, basic counseling, team building, and the impact of HIV/AIDS on young people. The training was successful insofar as it reduced staff tensions; mentors gained sufficient understanding of credit officers' duties they they were able to stand in for credit officers whenever they were late for meetings.

Other challenges persisted for the TRY mentoring program. Although mentors were paid as part-time workers, many resigned when they found betterpaying jobs. Those who had university degrees were particularly attractive to prospective employers. An ongoing challenge was finding adequate space and time for girls' interaction with mentors. Meeting venues were often rented, and the time spent in them was constrained. In rented locations, priority was usually given to the savings and credit activities, with little or no time remaining for mentoring. The mentors that remained with TRY for the long term were older, more financially stable, and more experienced women, some of whom had adolescent children of their own.

\section{Personal Savings}

The importance of girls' having personal savings that are under their own control became apparent in the early stages of the project. Data from the baseline survey revealed that 28 percent of girls in the control group (nonparticipants) ${ }^{11}$ had already started to save, as had 57 percent of TRY participants. The latter figure may overstate the prevalence of savings among the Nairobi groups because some of these girls had already begun to save through their TRY groups before they were interviewed. The median amount of savings among the nonparticipants was KSH 2,000 (\$26). Girls saved money for a variety of reasons, but the reason they gave most often was to have a cushion in case of emergency

\footnotetext{
${ }^{11}$ TRY girls and controls are considered separately in order to understand the prevalence of savings among Nairobi girls. In the TRY project, saving starts fairly soon after enrollment, and many girls may have started to save before they were interviewed at baseline, thus inflating the estimate of the proportion of TRY girls who have savings.
} 
such as sickness or death. Saving money in order to start a business or saving to develop a financial track record as a basis for taking a loan were much less important reasons for putting money aside than was concern about future events ${ }^{12}$ :

[Savings] can help in the future. When you are married, you have to have some savings. If you are ditched, you can start your business and educate your child.

—Age 23, married, eight years of education

[I save] in case of any emergency, like sickness, so that I can have money to take the baby to the hospital. Also, in case you are arrested by the police, you need some money to bribe them, because this area is so bad.

-Age 20, married, ten years of education

The girls in the project site reported two main motivations for saving, one related to economic security and having a safe place to keep their savings and the other linked to an interest in accumulating resources to take advantage of livelihood opportunities. In the early days of TRY, project managers considered having a savings account to be part of the process leading to taking out business loans. For a few girls in the group, saving meant being able to borrow more rapidly. For others, however, the purpose of savings was less clearly articulated; it related to personal and family security, asset purchases, or future education and work goals. If at the beginning of the project, girls' interest in savings had been studied according to their motivations, a critical learning process might have been accelerated. Although pres- sure from girls for different kinds of savings built up over the course of the project, for the first two phases of the experiment, savings remained mandatory, inaccessible to individual TRY group members, and used as group collateral for loans. No alternatives for personal savings were offered except for informal participation in merry-go-rounds.

In 2001, an opportunity arose to revise the program's approach according to the findings of the evaluation, which specifically recommended voluntary, flexible savings products not linked to loans, for girls not ready to be given credit. This revision was discussed at length with top program managers, and market researchers focused on the demand for savings products among adolescents. Although considerable enthusiasm and support for the idea emerged, it was not implemented until 2004.

One limiting factor was logistics. Most girls lived a considerable distance from K-Rep Bank and other banks, which posed a security risk for the member whose turn came to collect savings during the meeting and transport the funds to a bank branch. K-Rep staff were few in number and overstretched in working with such a large, complex intervention that included the mentoring program and the addition of experimental male groups. Moreover, some members may also have hesitated to put additional savings into group accounts for fear that their funds would be used to cover other members' loan repayments.

A number of TRY members contributed to the collective savings program, borrowed, and repaid their loans while maintaining positions in informal merry-go-rounds. The discontent some members felt about their lack of access to

\footnotetext{
12 Forty-three percent of girls in the control group who had savings mentioned future emergencies as their main reason for saving. In contrast, 20 percent mentioned wanting to buy personal items such as clothing and toiletries, 16 percent mentioned wanting to invest in a small business, and 15 percent mentioned education for themselves, for their children, or for other family members.
} 
their savings and the role of this feeling in causing a high drop-out rate were masked by other events at different phases of the project. As described above, during the pilot phase of TRY, the temporary absence of a well-liked credit officer sparked some members' early withdrawal from the program. Even after K-Rep provided refresher training on credit policies and procedures, high attrition rates continued during TRY's second phase. Table 6 lists reasons determined for member's dropping out during the second phase of TRY. The most frequently mentioned reason for leaving the program was the delay in receiving loans (20 percent). Another 18 percent mentioned not having enough money to save or needing access to their savings. Another factor contributing to the drop-out rate was poor interpersonal relations (15 percent reported poor relations within the group, 8 percent spoke of the disintegration of the group, and 6 percent mentioned disagreements with credit officers). Clearly, several of these factors were related to the program design, specifically: (1) the rigidity of the savings requirement; (2) the members' inability to access their savings in an emergency; (3) the pressure to continually save and take out loans; and (4) the interdependence of the girls to guarantee loan repayments and savings contributions. One participant expressed her feelings thus:

I had already saved about 1,000 shillings [\$13] with K-Rep, and they were delaying about giving me the loan. The CO [credit officer] kept telling me to wait for those who already have loans to repay, and then I could be given a loan. I got annoyed and decided to leave.

-Age 20, never married, six years of education

A delay in receiving a loan meant that girls waiting for loans still were required to contribute savings into an account to which they had no access and that could
Table 6 Percentage of girls who dropped out of TRY, by their reported reasons for dropping out

\begin{tabular}{lr} 
Reason & $\begin{array}{r}\text { Percentage } \\
(\mathbf{n}=\mathbf{1 2 9})\end{array}$ \\
\hline Delay in receiving a loan & 20 \\
Could not make contributions required for & \\
withdrawing savings & 18 \\
Poor personal relations within the groups & 15 \\
Other opportunities (schooling, employment) & 15 \\
Had no time for meetings & 13 \\
Could not repay loan & 9 \\
Dropout of other member(s)/disintegration of group & 8 \\
Disagreement with credit officer & 6 \\
Fines for lateness or nonattendance & 3 \\
Husband's opposition & 3 \\
Did not want a loan & 3 \\
Sickness & 3
\end{tabular}

Note: Percents add to more than 100 because respondents could give more than one reason.

Source: Exit interview.

be confiscated because others defaulted on their repayments. As delays increased, group members became concerned about their savings, and poor relations developed between members and with the credit officer.

When members understood that they could not access their savings unless they left the program, those who needed their savings had no choice but to drop out.

To me, it is not logical. When I joined, the CO told me that I could get my savings any time in case of emergency, but when I actually needed my money, I found that it was impossible to get it.

-Age 21, married, 12 years of education

Moreover, when loan repayments began to dip generally, many girls were worried that their savings would be confiscated to repay the loan of a delinquent comember, another factor contributing to the dropout rate. Many also left the project when their loans were delayed because their comembers failed to make the required contributions to savings and loan repayments. 
I got bored with the group because [the $\mathrm{CO}$ ] refused to give me a loan, claiming that some of my watano had not paid back their loans. I was annoyed because she claimed that I wouldn't get back my savings, that I would offset loans paid out to my watano. I thought that was very unfair to me since I had repaid my first loan.

—Age 25, never married, 12 years of education

The credit officer refused to give me a loan even after I had qualified. She claimed that our group members were running away with loans, but not everyone is the same. Does she think I will run away? Anyway, I decided I might as well quit and take my money.

-Age 20, married, 11 years of education

Recognizing the limited effectiveness of group guarantees as an alternative form of collateral among vulnerable girls, K-Rep introduced an additional guarantee/collateral mechanism that required girls to present an adult guarantor who pledged his or her assets against the loan. As previous credit programs for vulnerable groups in Kenya had discovered, the introduction of adult guarantors did not work well. Some TRY credit officers began to employ strict disciplinary measures-in some cases, exaggerated measures - to ensure compliance. Understandably, girls with so few resources found it difficult to present guarantors willing to pledge their assets and felt intimidated by the credit officer. TRY membership continued to decline.

I differed with the $\mathrm{CO}$ because she took us to the chief. She did not want to understand that we had problems paying.

-Age 21, married, nine years of education

I left because of the way the CO dealt with me, trying to fight me outside my house and embarrassing me in front of my neighbors just because of 4,000 shillings.

-Age 21, married, 11 years of education
Faced with these defections, managers reflected on the evaluation of the pilot program in 2000 and promoted the idea of offering flexible and valuable savings:

[B]ecause the project savings are linked to credit groups and loans and not accessible to the members until they leave the program, their impact or potential in reducing risks and expanding options has been limited. Voluntary and flexible savings products can actually play an important role in reducing risks and expanding options for adolescents and young women. They can do so by providing a financial asset, or more simply a 'chunk of money' when it is needed to meet emergencies and other financial needs and to take advantage of opportunities when they present themselves. In this way, savings can be used as part of an individual or household strategy for managing risks and pursuing individual and household economic goals. Appropriate savings mechanisms are a way for adolescent girls to control their income and accumulate a financial asset they can draw upon in times of need. Savings can provide a safety net to allow adolescent girls to negotiate within relationships or avoid and exit unsafe relationships. (Sebstad 2001: 14)

Although the girls saw the value of saving and recognized that putting money aside would provide a cushion against emergencies, many were forced to save their money in places they did not consider secure. Nearly 60 percent of girls who had savings held their savings at home; 32 percent of these girls felt that option to be unsafe. A minority saved their money in a post bank (22 percent) or a commercial bank (6 percent), both of which they perceived as safe. More than half (57 percent) reported that they could not confide the information that they are saving to someone close to them, usually their husbands (among ever-married respondents) (66 percent) or their parents (23 percent). 
Whenever I tell him about my savings, he spends it on his own things, so I prefer not to tell him.

-Age 20, married, education unknown

Because as a woman I need money for my little problems, I don't even want him to know where my piggy bank is, because he can take the money and use it.

—Age 20, married, eight years of education

I would like to use the money for my children's education, but I am afraid if I tell my mother, she will persuade me to use the money on other things like buying food when she has no money.

-Age 24, never married, 12 years of education

Increasingly, by 2004, the TRY savings mechanism clearly was not reducing girls' vulnerability but increasing it. Attention had to be refocused, shifted to providing girls with safe and accessible savings opportunities. Moreover, as the experiment showed, financial programs designed for young people must acknowledge adolescents' age and relative inexperience with many aspects of money management and the importance of their gaining rudimentary financial skills before obtaining access to credit.

\section{$X$. The Young Savers Clubs}

With the understanding accumulated during the six years of the project's life, TRY managers worked to develop personal savings alternatives for adolescent girls, not as a replacement to the existing model, but as a supplement to it. The original TRY model was appropriate for some girls. Many of the older girls had acquired the necessary social capital and skills and the rudiments of business acumen that allowed them to jump into a group-lending program. The program had not consciously targeted these girls; it had sought to engage the more vulnerable, disenfranchised, and often younger girls. The alternative savings mecha-

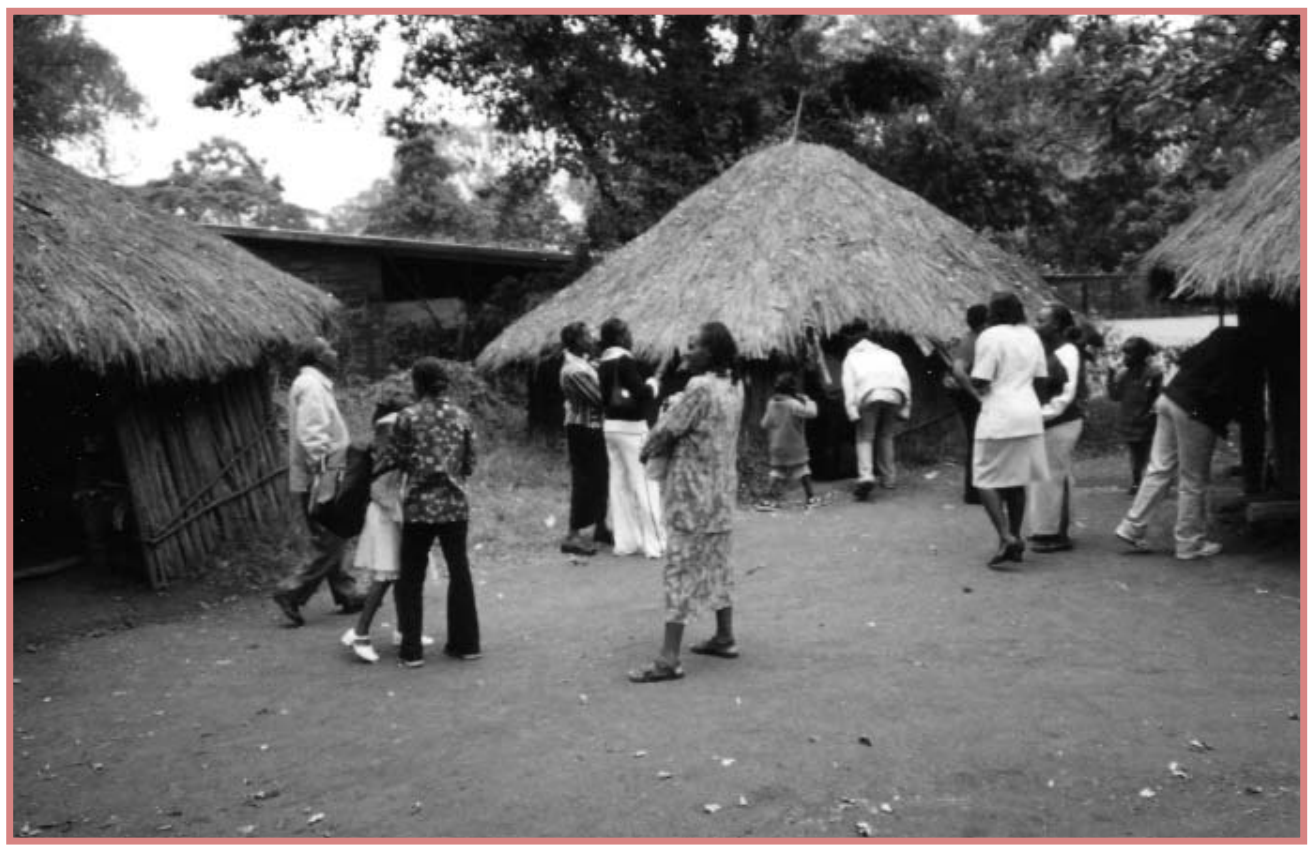


nisms were developed specifically for these less mature adolescents.

In early 2004, the Young Savers Clubs were established. They were designed to be independent from the TRY juhudi groups. Young Savers were recruited through existing TRY members, credit officers, and mentors, and through other community members such as social workers. As with TRY, members of the Young Savers Clubs form themselves into groups consisting of 20 to 25 members and conduct weekly meetings that are led by a credit officer or by a mentor. By the end of 2004, four Young Savers Clubs had been formed; one of the four disbanded early. Collectively, 123 girls have become Young Savers Club members and were contributing savings, even if not on a regular basis. In the initial stages of the clubs, fewer younger girls joined than the planners had expected. Only 26 percent were younger than 20. Outreach to younger clients was inadequate in the clubs' early stages, and many of the new members were either referred by TRY members or were former TRY members who wanted to take a break from borrowing.

When clubs are formed, group members pay an initial registration fee of KSH 20 (\$0.26), and purchase a passbook for KSH 30 (\$0.39). They hold weekly meetings in community social halls, churches, and other venues to which they can arrange access. Unlike TRY groups, the Young Savers Clubs are not always led by a credit officer but often by a mentor. Also, unlike TRY groups, they do not register with the Ministry of Gender, Sports, Culture and Social Services, partly because the application fee for registration as a self-help group is KSH 500 (\$6.50). The meeting is organized like TRY groups, with a roll call of members by the group chairwoman after which members deposit savings with the treasurer, using the passbook system. Groups meet on a weekly basis and hold discussions, engage with mentors, and participate in recreational activities such as sports, fitness exercises, and games. Savings are held in one large account maintained by K-Rep for all the savings groups. Should an individual want to withdraw money, she fills out a withdrawal slip, and she receives the money the following week. Members appreciate being able to keep their money in a safe place, and many mentioned that the club allows them to be disciplined about money matters:

I have tried [saving money at] home many times, but I see something like shoes, and I break the tin and use it [the money]. With Young Savers, the money is safe because it is in the bank. It cannot be given to someone else, like my husband when he sees something he wants to buy with my money.

-Age 19, married, no children, nine years of education

Like many girls in the TRY groups, the club members appreciate the friendships they gain and the opportunity the club offers for them to learn:

What attracted me, apart from saving, are the seminars. I especially like the way we are taught about how to run businesses and about nutrition and keeping fit. We do exercises for about 20 minutes. It also takes away my idleness. In the group, problems-even individual problems-are less troublesome when we share them.

-Age 20, married, one child, eight years of education

Group formation is slow because most girls are not easily reached through existing groups or clubs, and spreading information about the scheme takes time. Some members report that although weekly savings contributions are not mandatory, they feel a tacit pressure to contribute savings every week, which makes them feel uncomfortable about attending meetings empty-handed. Mem- 
bers request additional activities such as seminars, picnics, and sports events, which presents a continuing challenge to the club organizers.

\section{A New Savings Option for Members}

Initially, voluntary individual savings groups were considered as a means for the TRY girls to have a break between taking out loans-especially for those girls who wanted to step outside their watanos but who did not want to face censure. K-Rep was concerned that the availability of voluntary savings clubs might lead to a mass defection of girls from TRY and that the ongoing lending mechanism would be lost both to K-Rep and to the group of girls for whom loan schemes were manageable. The decision was eventually made to allow TRY girls to join a second savings scheme. Members of TRY groups were offered their own savings passbook, and they were able to access the funds in the second account whenever they wanted and could add and withdraw money freely as often as they wanted.

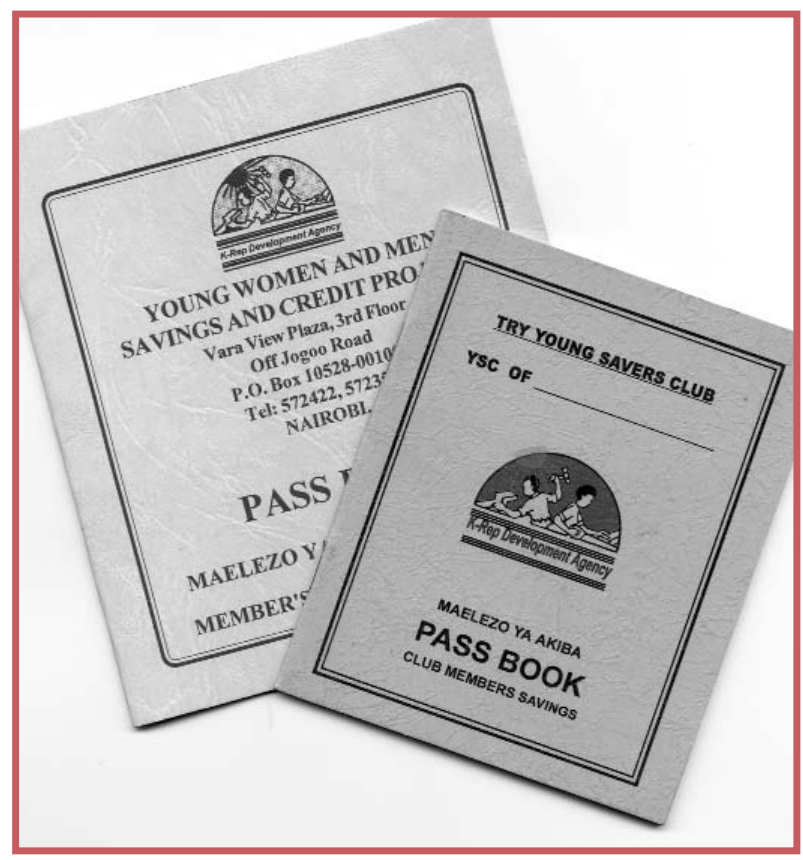

The second savings option for girls already successfully engaged in the TRY program provided a natural experiment with the demand for savings. Nearly all TRY members opted for having voluntary savings in the Young Savers Clubs. By June 2005, 83 percent of current TRY members had also become members of Young Savers Clubs. Girls have the options of cashing out of their TRY groups and joining Young Savers Clubs or of opening a second account and expanding their savings levels in order to enjoy the benefits of a personal account. The enthusiastic adoption of membership in the Young Savers Clubs is probably the most powerful indicator of the importance of stand-alone savings to young women.

\section{More Than Just Repayment Rates: The Impact of Savings and Group-lending Programs}

The TRY experimental program is one of the first attempts in sub-Saharan Africa to offer professional and well-documented microfinance services to an extremely poor, vulnerable, HIV-affected population. The TRY experience offers valuable programming lessons to the world of microfinance, to programmers working with young people in general, and to those working to improve the livelihood options of adolescents. Table 7 shows the achievements of the project through August 2004.

A common benchmark of microfinance institutions' performance is repayment rates. This indicator of success has become so often acknowledged that it carries inappropriate weight even among health and development organizations engaged in livelihoods projects. Repayment rates and other financial indicators are legitimate indicators of program performance, but they reveal little about 
Table 7 Achievements of the Tap and Reposition Youth (TRY) program through August 2004

\begin{tabular}{|c|c|}
\hline Number of groups formed & 20 \\
\hline Number of members & 431 \\
\hline $\begin{array}{l}\text { Gross savings, including } \\
\text { savings clubs }\end{array}$ & KSH 1,329,106 (\$17,278) \\
\hline Number of loans disbursed & 520 \\
\hline Average loan size & KSH 11,274 (\$147) \\
\hline Amount disbursed in loans & KSH 5,862,700 $(\$ 76,215)$ \\
\hline Amount of loan repayments & KSH 4,767,705 (\$61,980) \\
\hline
\end{tabular}

the effectiveness of these programs from the clients' viewpoint. Development and long-term performance of financial services also must be assessed in terms of noneconomic benefits. Where poverty is extreme and other profound threats loom, such as HIV/AIDS, programs that are truly beneficiary-driven must take into account their performance in terms of social engagement and asset building for vulnerable subgroups. Implicit in a focus on repayment rates is the emphasis on the question "Is the program sustainable?" Partners in TRY asked a different set of questions, however: "Does TRY benefit participants and in what ways?" and "Is TRY more effective for particular subgroups, such as those differentiated by age, economic status, or marital status?"

The effectiveness of TRY was evaluated through pre- and post-test intervention surveys among participants and among controls who were selected on the basis of their similarity to participants in terms of age, residence, education, and work, marital, and childbearing status. The TRY evaluation examined the impact of participation across social, economic, and health dimensions and determined its relative effectiveness for older and younger adolescents. Research hypotheses considered a range of issues including income, work roles, household decisionmaking and con- trol of resources, social networks, and patterns of partnership, sexual behavior, and HIV risk. Researchers were not able to evaluate all of these hypotheses, largely because of low sample sizes. ${ }^{13}$

Those tested were: (1) Participation in the TRY program contributes to increases in individual income; (2) participation in the TRY program increases the individual's savings; (3) participation in the TRY program increases members' material assets; (4) participation in the TRY program increases girls' mobility and exposure to nonfamilial social networks; and (5) participation in the TRY program increases girls' ability to gain control over sexual relations, including their ability to negotiate safer sex.

\section{The Economic Impact of TRY}

TRY did, in fact, have a significant impact on girls' earnings and savings. At both baseline and endline, TRY girls were significantly more likely than girls in the control sample to have savings. That a large number of TRY members were saving could reflect their interest in business (a criterion for joining TRY), and their savings may have been put aside in anticipation of opening a business. Although the TRY girls were more likely than the girls in the control sample to be savers, the amount of their savings was significantly less than that of the control savers at baseline. (Whereas at baseline, the TRY members had saved an average of KSH 3,308 [\$43], control girls had saved an average of more than KSH 5,385 [\$70].) By endline, TRY girls had more than doubled their savings (for a mean savings of KSH 7,308 [\$95]), and the mean savings they had accrued was significantly larger than that of the control group (KSH 5,145 [\$67]). Whereas only about one-fourth of TRY members and the control sample re-

\footnotetext{
${ }^{13}$ Hypotheses that were not tested because of sample-size constraints were: (1) that participation in the TRY program increases participation in household economic decisionmaking, and (2) that participation in the TRY program helps girls leave sexual relationships that are harmful or dangerous.
} 


\section{How TRY Changed the Life of One Participant}

Wanjiku (not her real name) was introduced to K-Rep by a friend in 2002, shortly after giving birth to her first child. At the time, Wanjiku, aged 21, was living with her own single mother upon whom she depended entirely for support when her boyfriend abandoned her after she became pregnant. Wanjiku joined a TRY group in Majengo where she lived and started saving KSH 50 $(\$ 0.65)$ every week, most often borrowing the money from her mother. During her first six months in TRY, Wanjiku attended weekly meetings, contributed savings, and participated in business-management training and seminars on HIV/AIDS. She applied for a loan of KSH 10,000 (\$130) and opened a small stall serving local food items (chapatti, ugali, irio, and getheri) in an open market, using the income to rent a kiosk and buy cooking materials and ingredients. As her business picked up, she earned an average of KSH 500 per day (\$6.50) and opened a savings account with Akiba Bank. Her goal was to save KSH 200 (\$2.60) every day, and she made a trip to Akiba once a week to deposit her savings. As her business continued to expand, she received orders to supply fruit salad to office workers in town and in the industrial area. By 2003, she was employing two people to prepare food and deliver orders. Eventually, she moved from her mother's house in 2004, rented her own house, and employed house help. By the time Wanjiku was ready to apply for a second loan in 2004, her TRY group had dissolved, but she was transferred to another group by the credit officer. She attributes her success in TRY to the loan and to the business training she received

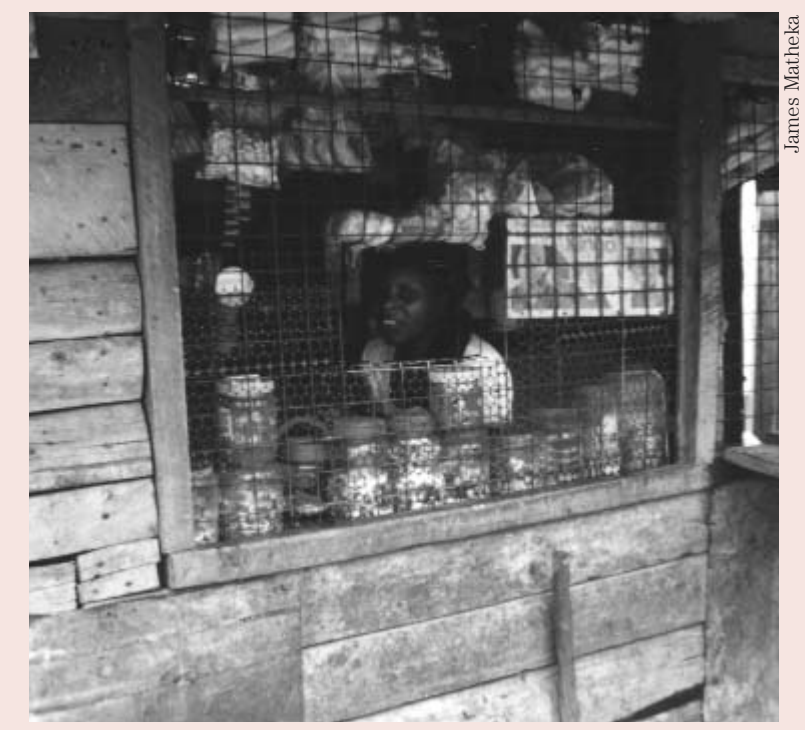

ported saving in a bank at baseline, by endline, TRY girls were considerably more likely to save in a bank, compared with the control girls (42 percent and 24 percent, respectively).

Because younger members were more likely to drop out of TRY, the relative effectiveness of the program for older versus younger participants was examined. At baseline, respondents were categorized by age group: younger than 20 and 20 and older. The effect of financial indicators for older girls appeared to be greater than for younger girls. Older TRY participants were substantially more likely than younger girls to have greater numbers of household assets, larger incomes, and greater savings, and they were significantly more likely than younger girls to keep their savings in a financial institution. The effects of the program on young participants were weaker; younger TRY participants had greater incomes and savings compared with control girls, although the difference was only marginal. No 
effect on economic decisionmaking in the household was detected, perhaps because the sample sizes were small.

\section{The Impact of TRY on Reproductive Health Knowledge and Sexual Behavior}

TRY participants were not more knowledgeable than girls in the control sample about reproductive health issues, but they seemed better able to negotiate sexual relationships. At the same time, they held more liberal gender-role attitudes than the control girls-measurable differences that were statistically significant. Respondents were asked about their ability to negotiate within their current relationships with husbands or boyfriends. They were asked if they were able to stop their partner from drinking, were able to refuse sex, or were able to insist on the use of a condom or other contraceptive. At baseline, no statistically significant differences between TRY participants and controls were found in terms of ability to negotiate these aspects of their relationships. Overall response rates at endline were relatively low (68 percent), suggesting that results should be viewed with caution. TRY girls' responses showed that they were significantly more likely than girls in the control sample to be able to insist on condom use and to refuse sex. TRY participants were more than 1.7 times more likely to be able to refuse to have sex with their partners and nearly three times more likely to be able to insist on condom use, compared with control girls. Similarly, although condom use is not statistically significantly higher among TRY girls than among controls, their participation in the decision to use a condom is higher. The effect of the TRY project on sexual negotiation did not differ by age of participants or by the length of time they were in the program.

\section{Repayment Rates and Cost}

TRY's repayment rates were lower than standard (50 percent by December 2004), probably as a result of the program's experimental nature and its focus on learning what works best for adolescents in terms of strategic approach and livelihood interventions. The partners in TRY consider losses in repayment as tradeoffs for other benefits that the girls accrue, such as social connections, increases in savings, and increased control over reproductive risks. Moreover, although the program may not reach operational sustainability, its cost-effectiveness in terms of achieving these benefits is likely to be higher than that of other programs for young people. For example, in South Africa, the cost of a peer-education program (including training, workshops, supervision, and other expenditures) ranges from $\$ 2$ to $\$ 20$ per peereducator contact, without a proved behavioral impact (Janowitz et al. 2003). Youth centers are similarly expensive or more so; the annual running costs of such centers range from $\$ 20,000$ to $\$ 80,000$.

A neglected but important benefit in assessing the cost-effectiveness of livelihood programs is their role in creating venues in which to extend reproductive health and life-skills information and support, including information related to HIV/AIDS to out-of-school adolescents. In most developing-country settings, few opportunities arise to reach adolescents who are not attending school and the scant infrastructure that organizes them. The most socially isolated and economically vulnerable adolescent girls are the least likely to be reached. Group-based livelihood programs attract adolescents and can function as vehicles to prepare them for their economic lives and also to deliver education, information, and social support. In evaluating the cost-effectiveness of programs for adolescents and the benchmarks of their success, the full 
range of benefits must be captured and compared with other ways of reaching and supporting this heterogeneous group with evolving capacities.

\section{The Way Forward and Recommendations}

TRY was an important and valuable experiment in adapting livelihood models for the most vulnerable adolescents in urban slum settings. It taught a number of useful lessons about the heterogeneity of adolescent girls living in the same urban environment, the importance to these girls of savings, of mentorship, and of staged interventions that support them as they make the transition to adulthood.

\section{The Heterogeneity of Adolescent Urban Girls}

Adolescents are a particularly heterogeneous group, facing diverse circumstances even within the same limited environment. They are living in a period of rapid transition, as the various situations of TRY participants demonstrate. At baseline, about two-thirds of participants were single, one-fourth were married, and one-tenth were divorced or separated. Roughly half had children and half did not. Roughly half had received only a primary education and half had reached secondary-school level. More than half were living apart from their parents, one-fifth were living in singleparent households, and only 16 percent were living with both parents. More than half had migrated to Nairobi, most coming to find work. Their sexual experience was varied: 85 percent had had sexual intercourse, among whom only 37 percent had wanted to have sex at the time of their initiation. Forty-five percent of girls had experienced coerced sex or sex resulting from trickery, 24 percent had been promised money or gifts in exchange for sex, and 69 percent did not know the HIV status of their

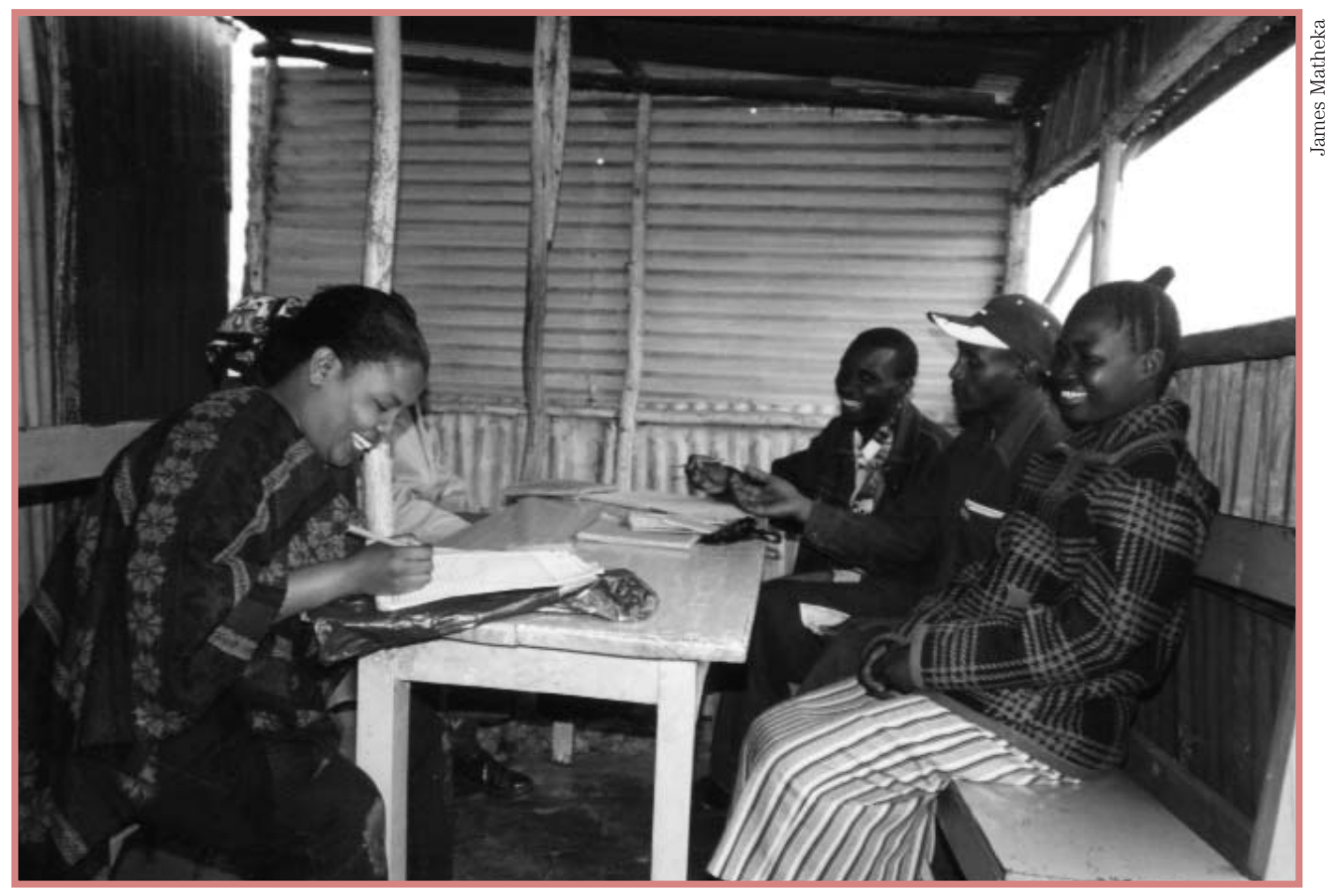


partner. The interplay between girls' personal situations - the instability of their living arrangements and personal relationships-dictates, to some extent, the need for great flexibility in programs designed to serve them.

\section{The Importance of a Place to Save}

The evolution of TRY underscored the realization that a voluntary savings opportunity is universally and highly valued among these girls, regardless of their circumstances. Eighty-three percent of the girls who were successful borrowers joined the voluntary savings program in its first year, adding to their group collateral savings and informal merry-go-rounds. Even among girls who were not ready for credit or not successful at borrowing, a great demand was expressed for a safe and accessible place to keep their money as a strategy for building financial security. For many girls, their engagement in a savings group was also their first form of civic participation, which suggests that microfinance and other financial institutions reaching out to engage vulnerable girls should be mindful of these girls' lack of contact with other socializing and supportive organizations.

\section{Social Support and Mentoring}

The TRY experiment revealed girls' need for adult mentors and confidantes. It made clear that those serving as mentors should not have simultaneous and competing roles. Programs seeking to offer social support should distinguish clearly between the roles of credit officer and mentor because the girls need to be able to discuss the problems they have with savings, loans, and other financial demands and not feel that they have to hide these problems from their new adult friends. Mentors should be chosen with girls' requirements in mind: They need someone they can talk with about diverse subjects, someone who is not concerned about their loan repayments but is concerned about their ability to make their way to adulthood. The most successful TRY mentors were those who lived in the girls' community, who understood the circumstances they face, and who were happy to have a part-time job as a source of small, regular income.

The experiment revealed that providing girls with savings accounts, passbooks, and identity cards has profound symbolic meaning for them beyond financial security. It validates girls' personal identity and encourages their growth.

\section{Microfinance Institutions and Their Ability to Stretch}

The microfinance industry will not grow without bold innovators like K-Rep that are willing to take risks and share programmatic lessons through frank discussion of experiences. Some microfinance institutions (MFIs) are interested in reaching out to the most vulnerable of social groups, not only as a matter of expanding their markets, but also as socially responsible business practice. The flexibility and truth-seeking of institutions such as K-Rep are invaluable for reaching the most vulnerable groups.

The TRY experience suggests that the classical group-lending model may be appropriate for more mature, less vulnerable adolescent girls and young women but may be impractical and even hostile to the most vulnerable adolescent girls. Reduced collateral, more intense mentoring, and lower interest rates may be insufficient adjustments, because many of these girls' lives are extremely fragile. In such circumstances, group-based lending is unlikely to achieve the objective of improving such girls' lives and capabilities. Group 
mobilization and support using individualized credit plans after conducting a specially adapted screening process may have a greater chance of success, compared with a group-based model that requires girls to risk precious savings as loan collateral for other girls in the same situation.

A key issue for adolescent livelihoods programs is how to link microfinance institutions to other organizations that provide necessary social support and nonfinancial services. These institutions cannot be expected to give up their sustainability goals to incorporate social support services for adolescents and young people directly into their structures. The K-Rep experience-although implemented by a flexible and innovative unit-reveals the conflicting roles of staff and the costs and sustainability tradeoffs that would be required for a mainstream institution that wished to pursue an integrated approach. These organizations cannot afford such tradeoffs. They can adapt the design of their products and delivery methods to some extent to meet poor young peoples' needs and opportunities and to reduce some of the risks experienced by younger clients, but they must also achieve efficiency and standardization in their service-delivery models. One programming challenge concerns forging effective links between microfinance institutions, youth-serving organizations, training institutes, and other nonfinancial service providers that can work effectively with adolescents. Another challenge concerns staging and sequencing services to match the needs of different groups of adolescents at different stages of their readiness for economic participation.
MFIs are relatively inexperienced in providing social support and mobilization. They should establish links with nongovernmental organizations that can serve as entry points for young people in their efforts to learn about money management. Small, voluntary savings groups could link not only to MFIs but also to partners with different mandates, credit unions, savings associations, and savings banks. A conscious, tiered training strategy teaching financial literacy can help to prepare young people for effective future use of banking services. Not all adolescents (or adults) can become entrepreneurs, but financial services play an important part in their economic lives, nevertheless.

\section{Programming for Differing Conditions and Evolving Capacities}

Girls' capacities are as diverse as their situations. For some adolescent girls, maybe 10 percent, a relatively demanding adult microfinance model will work. ${ }^{14}$ For another group of girls-perhaps 30 percent ${ }^{15}$ - the value of social interaction and camaraderie was so great and the potential for improvement of their financial situations so greatly desired that girls struggled to meet the groups' requirements, and many eventually dropped out when the pressure of repayment became too great. For most girls, however-perhaps 60 percentmandatory savings and repeated borrowing are not priorities. Rather they need more basic and critical interventions related to social capital, including social support groups, friendships, men-

\footnotetext{
${ }^{14}$ This estimate is based on the proportion of girls who succeeded at repeat borrowing.

${ }^{15}$ This estimate is based on the proportion of girls reporting that repaying the loan was "difficult" or "very difficult."
} 
tors, physical safety, and the opportunity to save money in a safe, accessible place. In the first phase of TRY, girls who were not prepared for the rigorous microfinance model felt stigmatized because they were unable to contribute to a mandatory savings fund or take out successive loans. The financial risks they were required to take through the program were not reasonable in relation to their situations or their experience.

Such girls require a strong group structure as a base; the model should be constructed as a positive experience, with benchmarks of success based on their capabilities and goals, such as individual voluntary savings or goal-oriented savings. These most vulnerable girls need a place apart from family for dialogue, support, crisis intervention, protection of savings, and development of rudimentary livelihood skills. When fundamental social capital is in place for these girls, their ability to make use of economic options will surely follow. Table 8 presents an illustrative staged model designed for accommodating girls in different circumstances and at different levels of capability.

Adolescent girls' capacity for developing livelihoods, for civic participation, and for self-protection grow and evolve over time, and the conditions of their first entry into a microfinance program should be supportive. The phased model begins with entry-level savings and skills-building related to life skills and financial skills. This entry-level phase is designed especially for girls who are young, unassertive, vulnerable, living in constrained circumstances, and having few skills or few social supports. Such

Table 8 Staged program model for adolescents, by type of program, according to type of beneficiaries and providers

\begin{tabular}{|c|c|c|c|}
\hline Type of program & $\begin{array}{l}\text { Program activities for younger, } \\
\text { more reticent adolescents living } \\
\text { in constrained circumstances }\end{array}$ & $\begin{array}{l}\text { Program activities for older, } \\
\text { bolder adolescents living in } \\
\text { better circumstances }\end{array}$ & Providers \\
\hline Social intermediation & $\begin{array}{l}\text { Group meetings in safe and } \\
\text { appropriate venues } \\
\text { Age-appropriate learning activities } \\
\text { Literacy and numeracy training } \\
\text { Life-skills training } \\
\text { Health education } \\
\text { Financial education } \\
\text { Leadership/group participation } \\
\text { Simple technologies } \\
\text { Livelihood-skills training } \\
\text { Rights education } \\
\text { Social support provided by mentors } \\
\text { Organized sports and recreation }\end{array}$ & $\begin{array}{l}\text { Vocational training } \\
\text { Technical training } \\
\text { Business-skills training }\end{array}$ & $\begin{array}{l}\text { Youth-serving } \\
\text { organizations } \\
\text { Vocational, technical, } \\
\text { or business training } \\
\text { institutions } \\
\text { Sports organizations } \\
\text { Informal education } \\
\text { programs } \\
\text { Other organizations } \\
\text { providing nonfinancial } \\
\text { services }\end{array}$ \\
\hline Financial services & $\begin{array}{l}\text { Promotion of savings linked to } \\
\text { financial education }\end{array}$ & $\begin{array}{l}\text { Credit } \\
\text { Other financial services } \\
\text { (insurance, money transfer) }\end{array}$ & $\begin{array}{l}\text { Microfinance } \\
\text { institutions } \\
\text { Credit unions } \\
\text { Banks }\end{array}$ \\
\hline Other & $\begin{array}{l}\text { Exposure to world beyond home } \\
\text { through visits and exchanges }\end{array}$ & $\begin{array}{l}\text { Work experience through } \\
\text { facilitation of apprentice- } \\
\text { ships, business mentoring, } \\
\text { and other on-the-job } \\
\text { training }\end{array}$ & $\begin{array}{l}\text { Youth-serving } \\
\text { organizations } \\
\text { Business-development } \\
\text { organizations } \\
\text { Business associations }\end{array}$ \\
\hline
\end{tabular}


girls can stay with the program and literally grow up within it, readying themselves to take on more demanding financial challenges such as goal-oriented savings, formation of a microcredit group, and negotiating initial and repeated loans. However the program is structured, it should provide some form of individual identification to foster the girls' sense of belonging and identity.

A second tier of this model is built for girls who graduate from the first phase or for those who are better equipped to handle a more rigorous microfinance program. Among the elements of the second phase would be vocational or business training, access to credit and apprenticeships, and on-the-job training. In the staged model, a young person may begin with individual savings and move toward goal-oriented savings. Successfully saving toward a goal builds a young person's sense of confidence, self-esteem, and self-reliance that struggling to repay a loan does not.

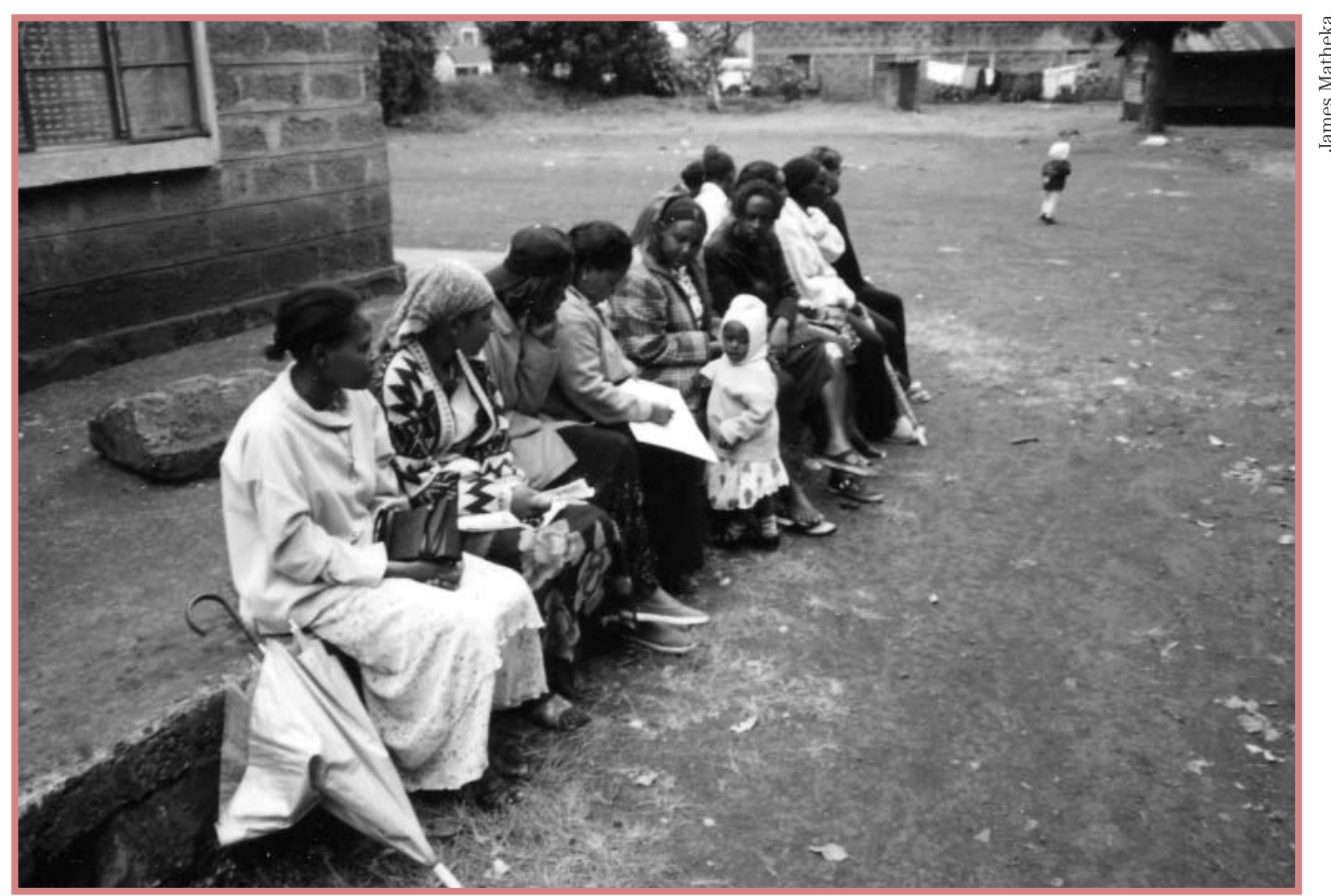




\section{References}

African Population and Health Research Center (APHRC). 2002. Population and Health Dynamics in Nairobi's Informal Settlements. Nairobi: APHRC.

Bruce, Judith. 2005. "Social and economic protection strategies for the adolescent girls left behind living in the path of HIV." Presentation made at the office of the Global AIDS Coordinator, Washington, DC. 18 May. Unpublished.

Central Bureau of Statistics (CBS), Ministry of Health (MOH), and ORC Macro. 2004. Kenya Demographic and Health Survey 2003. Nairobi and Calverton, $\mathrm{MD}$ : $\mathrm{CBS}, \mathrm{MOH}$, and $\mathrm{ORC}$ Macro.

Erulkar, Annabel S. 2004. "The experience of sexual coercion among young people in Kenya." International Family Planning Perspectives 30(4): 182-189.

Erulkar, Annabel S. and B. Khan. 1999. "Livelihoods and lifestyles of adolescent girls in Nairobi: Baseline report of a pilot savings and micro-credit project." Unpublished.

Erulkar, Annabel S. and Barbara Mensch. 1997. "Youth centers in Kenya: Evaluation of the Family Planning Association of Kenya program." Nairobi: Population Council. Unpublished.

Erulkar, Annabel S., Mags Beksinska, and Queen Cebokhulu. 2001. An Assessment of Youth Centers in South Africa: Preliminary Report. Nairobi: Population Council FRONTIERS Program.

Erulkar, Annabel S., Tekle-ab Mekbib, Negussie Simie, and Tsehai Gulema. 2004. "Adolescent life in low-income and slum areas of Addis Ababa Ethiopia." Accra: Population Council.

Garenne, Michel. 2003. "Migration urbanization and child health in Africa: A global perspective." Paper presented at the Conference on African Migration in Comparative Perspective. Johannesburg, 4-7 June.

Glover, Evam Kofi, Annabel S. Erulkar, and Joana Nerquaye-Tetteh. 1998. Youth Centers in Ghana: Assessment of the Planned Parenthood Association of Ghana Program. Nairobi: Population Council.

Government of Kenya. 1999. Kenya Population Census 1999. Nairobi: Central Bureau of Statistics, Office of the Vice President, Ministry of Planning and National Development.

Hallman, Kelly. 2004. "Socioeconomic Disadvantage and Unsafe Sexual Behaviors of Young Women and Men in South Africa." New York: Population Council Policy Research Division Working Paper No. 190.

Hallman, Kelly and Judith Diers. 2004. "Social isolation and economic vulnerability: Adolescent HIV and pregnancy risk factors in South Africa." Poster presentation at the Annual
Meeting of the Population Association of America, Boston, 1-3 April.

Janowitz, Barbara, C. Cuthbertson, M. Beksinska, and Q. Cebekhulu. 2003. "The costs of programmes at selected youth centers in South Africa." FRONTIERS report. Unpublished

Khan, B., E. Muia, and Annabel S. Erulkar. 1997. Profiles of Youth Organizations in Kenya. Nairobi: Population Council.

Lewis, Stephen. 2004. Statement by the U.S. Special Envoy for HIV/AIDS in Africa at the $\mathrm{XV}^{\text {th }}$ International AIDS Conference, Bangkok, 12 July.

Lloyd, Cynthia B. 2005. "Schooling and adolescent reproductive behavior in developing countries." Paper commissioned by the Millennium Project. Unpublished.

Mensch, Barbara, Judith Bruce, and Margaret E. Greene. 1998. The Uncharted Passage: Girls' Adolescence in the Developing World. New York: Population Council.

Mekbib, Tekle-ab, Annabel S. Erulkar, and F. Belete. 2005. "Who is being reached by youth programs: Results of a capacity-building exercise in Ethiopia." Ethiopian Journal of Health and Development 19(1): 60-62.

National Council for Population and Development (NCPD), Central Bureau of Statistics (CBS), and Macro International. 1999. Kenya Demographic and Health Survey 1998. Nairobi and Calverton, MD: CBS and Macro International.

Phiri, Alford and Annabel S. Erulkar. 1997. A Situation Analysis of the Zimbabwe National family Planning Council's Youth Centers. Nairobi: Population Council.

Rutherford, Stuart. 2000. The Poor and Their Money. New Delhi: Oxford University Press.

Sebstad, Jennefer. 2001. “Assessment of K-Rep's savings and credit project for adolescent girls and young women in Nairobi." Nairobi: Unpublished.

UNAIDS/UNFPA/UNIFEM. 2004. Women and HIV/AIDS: Confronting the Crisis. New York: UNFPA.

UNICEF (United Nations Children's Fund). 2004. State of the World's Children: Girls' Education and Development. New York: UNICEF.

United Nations University. 2004. "Kenya's Socioeconomic setting." <http://www.unu.edu>. Accessed December 2004.

Zulu, Eliya, Alex Chika Ezeh, and F. Dodoo. 2000. "Slum Residence and Sexual Outcomes: Early Findings of Causal Linkages in Nairobi, Kenya." African Population and Health Research Center Working Paper No. 17. Nairobi: APHRC. 


\section{SEEDS Advisory Committee}

Judith Bruce (Population Council)

Marilyn Carr (Consultant)

Marty Chen (Harvard University)

Monique Cohen (Microfinance Opportunities)

Caren Grown (Bard College, Levy Economics Institute)

Ann Leonard (Consultant)

Joyce Malombe (Institute of International Education)

Katharine McKee (USAID)

Aruna Rao (Gender at Work)

Mildred Warner (Cornell University)

Corinne Whitaker (International Women's Health Coalition)

Editor: Sandy Schilen

Editorial and Production Coordinator: Michelle Skaer and Sara Rowbottom

Copyeditor: Karen Tweedy-Holmes

Designer: Mike Vosika

Cover Photo: Karen Austrian

\section{Currently Available Issues of SEEDS}

No. 2 Hanover Street: An Experiment to Train Women in Welding and Carpentry_Jamaica (English, Spanish)

No. 3 Market Women's Cooperatives: Giving Women Credit-Nicaragua (Spanish, French)

No. 4 Women and Handicrafts: Myth and Reality-International (English, Spanish, French)

No. 5 The Markala Cooperative: A New Approach to Traditional Economic Roles-Mali (French)

No. 6 The Working Women's Forum: Organizing for Credit and Change-India (French)

No. 7 Developing Non-Craft Employment for Women in Bangladesh (English, French, Spanish)

No. 8 Community Management of Waste Recycling: The SIRDO-Mexico (English, Spanish)

No. 9 The Women's Construction Collective: Building for the Future-Jamaica (English, Spanish)

No. 10 Forest Conservation in Nepal: Encouraging Women's Participation (English, Spanish, French, Nepali)

No. 11 Port Sudan Small Scale Enterprise Program-Sudan (English)
No. 12 The Muek-Lek Women's Dairy Project in Thailand (English)

No. 13 Child Care: Meeting the Needs of Working Mothers and Their Children (English, Spanish)

No. 14 Breaking New Ground: Reaching Out to Women Farmers in Western Zambia (English, Spanish, French)

No. 15 Self-Employment as a Means to Women's Economic Self-Sufficiency: Women Venture's Business Development Program (English)

No. 16 Wasteland Development and the Empowerment of Women: The SARTHI Experience (French, Hindi)

No. 17 Supporting Women Farmers in the Green Zones of Mozambique (English)

No. 18 Out of the Shadows: Homebased Workers Organize for International Recognition (English)

No. 19 Empowering the Next Generation: Girls of the Maqattam Garbage Settlement (English, Arabic)

No. 20 Women Street Vendors: The Road to Recognition (English)

No. 21 Are We Not Peasants Too? Land Rights and Women's Claims in India (English)

No. 22 Women's Participation in Disaster Relief and Recovery (English)

For additional copies of this issue or any SEEDS issues listed above, send an e-mail to:

seeds@popcouncil.org or seedseditor@gmail.com. Copies of selected SEEDS issues in local languages have been published by organizations in the following countries: Egypt, India, Indonesia, Kenya, Nepal, Pakistan, Thailand, and Vietnam. Please write to us for more information if you are interested in these materials. Most past editions of SEEDS are also available online at: www.popcouncil.org/publications. 


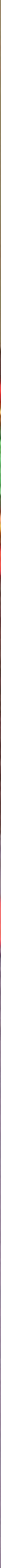

